\title{
Rehabilitation of timber structures: novel test method to assess the durability of bonded-in rod connections
}

\author{
João Custódio $\cdot$ James Broughton $\cdot$ Helena Cruz
}

Received: 8 June 2010/ Accepted: 20 June 2011

(C) RILEM 2011

\begin{abstract}
Rehabilitation/restoration systems involving bonded-in rods represent an efficient alternative method for the repair and/or reinforcement of structural timber members. However, in spite of their advantages, their use is still restrained by the lack of knowledge about their long-term performance. In order to correct this situation it is necessary to gain a greater understanding of their durability, creep and fatigue behaviour. However, reliable and realistic accelerated ageing tests do not yet exist, and the application of the existing European or American standards to epoxy bonded products are much too penalising, since they merely impose severe conditions that are not verified in service although these may be suitable for other adhesives. To address these concerns a test procedure to assess long-term behaviour of bonded-in rod connections was developed
\end{abstract}

J. Custódio ( $\square)$

Materials Department, Laboratório Nacional de Engenharia Civil (LNEC), Av. Brasil, 101, 1700-066 Lisbon, Portugal

e-mail: jcustodio@lnec.pt

J. Broughton

Joining Technology Research Centre, School of Technology, Oxford Brookes University (OBU), Wheatley Campus, Oxford OX33 1HX, UK

H. Cruz

Structures Department, Laboratório Nacional de Engenharia Civil (LNEC), Av. Brasil, 101,

1700-066 Lisbon, Portugal with the aim of providing a simple method for the selection of candidate repair system materials for specific applications. The data collected so far using the realistic performance assessment test (RPAT) appears to predict correctly the end-use performance for different adhesives as well as for different timbers.

Keywords Timber structures - Epoxy adhesives . Bonded-in rod connections · Durability - Realistic test

\section{Introduction}

Rehabilitation of buildings has an increasing economical and social importance in most European countries. The choice of the method employed is influenced by a number of factors, such as, location, structural requirements, access limitations, fire resistance, aesthetics, cost and the degree of intervention accepted. Current interventions often involve total replacement of the damaged timber by similar elements, instead of their recovery, even when that would be preferable, mostly due to the lack of knowledge of alternatives [1]. Rehabilitation/restoration systems involving structural adhesives represent an efficient method for the repair and/or reinforcement of both new and existing timber members in service classes 1 and 2 [2,3]. Epoxy adhesives have 
been used for many years in the repair and strengthening of timber structures, and are currently the most appropriate adhesive type for in situ applications [4, 5]. Despite excellent initial joint strengths when tested in standard climate conditions, there has been some concern over their service durability, yet reliable and realistic accelerated ageing tests do not currently exist $[6,7]$. Furthermore, the application of existing European or national tests and performance standards to epoxy bonded products (Table 1) are much too penalising, since they merely impose severe conditions that do not occur in service, or are inadequate because they were developed originally for other adhesives, namely for phenolic and aminoplastic adhesives. Moreover, current standard proposals developed for epoxy adhesives focus only on the initial bond quality control. The lack of standards in this field impedes the objective evaluation of the reliability of a bonded-in rod connection, causing engineers to avoid this type of solution altogether or sometimes commit errors that can lead to premature failure or reduced service life of the bonded connections [8].

The European Committee for Standardization (CEN) has already identified the need for development of standards for the evaluation of bond durability and long-term performance of epoxy adhesives, but so far, no standards are available [1,8].

To address these concerns a small number of studies have been conducted in the last couple of years in order to bring light to this matter.

Bainbridge et al. [21] conducted a study involving duration of load (DOL) tests and fatigue tests. The fatigue tests involved threaded galvanised steel rods with minimal preparation (simply wiping clean with alcohol prior to bonding) bonded with three adhesives types (a prototype formulation filled PRF, a commercial 2-part epoxy adhesive product and a commercial 2-part polyurethane product) into softwood glulam. Two sample geometries were tested, based upon $8 \mathrm{~mm}$ and $16 \mathrm{~mm}$ diameter rods, anchorage lengths of $160 \mathrm{~mm}$ on $576 \times 120 \times 120 \mathrm{~mm}^{3}$ and $576 \times 70 \times 70 \mathrm{~mm}^{3}$ specimens. An average bond thickness of $0.5 \mathrm{~mm}$ was employed. The fatigue tensile tests were conducted with a frequency at around $1 \mathrm{~Hz}$ with high loads at ambient conditions. The fatigue tests results indicated that the three adhesives performed quite differently (with the performance of the EP adhesives appearing to be better than PRF and PUR) and that the specimen geometry influenced the performance, so that more experiments were needed in order to fully characterize performance. The DOL experiments involved axial load tests of specimens made with $8 \mathrm{~mm}$ diameter threaded steel rods bonded into a block of glulam over a length of $160 \mathrm{~mm}$ with the same PRF adhesive and bond-line thickness. The specimens were subjected to constant loads in the region of 70$80 \%$ of the mean ultimate capacity in tension. The tests were conducted after being subjected in a laboratory to weathering conditions similar to those of outdoor UK climate for 1 year. The PRF specimens suffered failure in less time than anticipated. From the fatigue and DOL test it was concluded that different adhesive types behave in fundamentally different ways with respect to the mode of failure at

Table 1 Main characteristics of existing and proposed standards for evaluating the performance of structural adhesives [9-20]

\begin{tabular}{|c|c|}
\hline Standard & Limitations/inadequacies \\
\hline $\begin{array}{l}\text { ASTM D2919 } \\
\text { ASTM D3535 } \\
\text { ASTM D4680 } \\
\text { EN } 14292\end{array}$ & $\begin{array}{l}\text { Durability tests that: use exceptionally high loads; are complex, expensive, and labour intensive } \\
\text { systems; use lap-shear specimens; are based on very harsh and un-realistic ageing conditions }\end{array}$ \\
\hline $\begin{array}{l}\text { ASTM D2559 } \\
\text { EN } 301 \\
\text { EN } 302\end{array}$ & $\begin{array}{l}\text { Short-term tests that: do not involve loads during aging; are not designed for gap-filling adhesives; } \\
\text { evaluate thin bond-lines }(0.1-1 \mathrm{~mm}) \text {; are based on harsh and un-realistic ageing conditions }\end{array}$ \\
\hline $\begin{array}{l}\text { CEN TC193/SC1/WG11: } \\
\text { N21, N260 }\end{array}$ & Short-term tests that: do not involve loads during aging; are based on un-realistic ageing conditions \\
\hline $\begin{array}{l}\text { CEN TC193/SC1/WG11: } \\
\text { N22, N48 }\end{array}$ & Short-term tests that: do not involve loads during aging; evaluate initial bonded joint strength \\
\hline
\end{tabular}


ultimate limit states. With the tests performed, it was not possible to predict with confidence the failure mode and performance levels of these systems when in service.

Madhoushi and Ansell [22] contributed to the understanding and development of test methods for assessing the fatigue performance of repair/strengthening systems involving bonded-in rods. The study investigated static and tension-tension fatigue loading strength properties of bonded-in rod specimens, consisting on GFRP rods bonded into LVL and glulam cubes with an epoxy adhesive using two bond-line thicknesses ( 2 and $4 \mathrm{~mm}$ ). The effect of rate of loading was also assessed, ranging from 0.01 to $35 \mathrm{kN} / \mathrm{s}$, in three bond-line thicknesses $(0.5,2$ and $4 \mathrm{~mm}$ ). The results demonstrated that at lower rates of loading better static strength is obtained for thick bond-lines, and at higher rates the opposite is observed. In other words, thicker bond-lines are more sensitive to changes in loading rate. Bond-line thickness and rate of loading dictated the mode of failure observed, with the dominant failure in the $0.5 \mathrm{~mm}$ bond-line being cohesive failure in the timber, while in the $4 \mathrm{~mm}$ bond-line it changed to failure at the rod/adhesive interface. Thus, it was concluded that the epoxy adhesive was sensitive to rate of loading, and that the bond-line thickness is an important parameter in fatigue behaviour since increasing the bond-line thickness decreased the fatigue strength.

Therefore, although these systems are becoming better understood and more usable by designers and builders, adhesive material selection and performance assessment still poses a major obstacle to the realisation of their full potential. Thus, this article reports on a test procedure developed to assess the long-term behaviour of bonded-in rod connections, the aim of which is to provide a simple method and associated acceptance criteria for the selection of candidate repair system materials for specific applications. This test procedure is based upon the wider and more general knowledge available in the literature on bonded joint durability and associated test methods, and incorporates accelerated weathering conditions determined from real climatic conditions. It is also judged against the more traditional studies conducted on bulk adhesives properties reported elsewhere [1].

\section{Experimental programme}

The test method developed to assess and predict the long-term durability of bonded timber joints consisted of exposing loaded test specimens to natural (NW) or artificial accelerated weathering (AAW), and then to compare the periodically evaluated deformation and residual bond strength (RBS). The test campaign was designed to evaluate several parameters that could influence the performance and durability of the bonded joints. This included substrate type, adhesive type, load and weathering environment. Table 2 summarizes the test campaign, which comprised of 1,064 specimens. At the time this article was written the tests were still on going and, as such, only the results up to 12 months of exposure will be presented and discussed here.

\subsection{Expected environmental service conditions}

The environment to which joints are exposed plays an important role in their durability. In particular, when

Table 2 Description of the long-term tests of bonded and solid timber specimens (both for pine and oak)

\begin{tabular}{|c|c|c|c|c|c|}
\hline Weathering & Long-term loading & Rod & Adhesives & Test locations & Age (months) \\
\hline \multirow[t]{3}{*}{ Control $\left(20^{\circ} \mathrm{C}, 65 \% \mathrm{rh}\right)$} & - & $\checkmark$ & $\mathrm{A}$ and $\mathrm{B}$ & Oxford and Lisbon & 0 and 60 \\
\hline & & - & - & Oxford & 0 and 60 \\
\hline & $\boldsymbol{V}$ & $\boldsymbol{V}$ & $\mathrm{A}$ and $\mathrm{B}$ & Oxford & 12 and 60 \\
\hline \multirow[t]{2}{*}{ Artificial accelerated } & $\boldsymbol{V}$ & $\boldsymbol{V}$ & $\mathrm{A}$ and $\mathrm{B}$ & Oxford & $3,6,9$ and 12 \\
\hline & - & - & - & Oxford & 0 and 12 \\
\hline \multirow[t]{3}{*}{ Natural } & - & $\boldsymbol{V}$ & $\mathrm{A}$ and $\mathrm{B}$ & Oxford and Lisbon & 12 and 60 \\
\hline & & - & - & Oxford and Lisbon & 12 and 60 \\
\hline & $\boldsymbol{V}$ & $\boldsymbol{V}$ & $\mathrm{A}$ and $\mathrm{B}$ & Oxford and Lisbon & $6,12,24,36$ and 60 \\
\hline
\end{tabular}


exposed to the service environment, moisture and heat are the most important factors in determining the loss of bond strength. It therefore becomes vital to find out what conditions the bonded joints can be exposed to in service environment and what methods can be used to assess them. With this in mind, daily weather information (temperature and relative humidity) registered in Lisbon and London, and the air conditions registered in two timber roofs (one in Lisbon and one in Oxford) were compiled and analyzed. This allowed the determination of the expected service conditions to which a joint in this type of repair technique is likely to be exposed in both countries, and the definition of the artificial weathering conditions to which test joints will be exposed.

The weather conditions were obtained from the website of Weather Underground, Inc. [23]. The data selected was measured by a weather station located at Lisbon Airport (International Civil Aviation Organization code LPPT) and Heathrow airport (International Civil Aviation Organization code EGLL). The data set consisted of temperature and relative humidity values registered daily at $30 \mathrm{~min}$ intervals in Lisbon and London from January 2000 to December 2008.

In order to obtain differences between weather conditions inside and outside, the measurements made in the two monitored roof spaces were compared with those obtained locally from LNEC's weather station and from Oxford city weather station (The Big Oxford Computer Company Ltd.). The data set consisted of temperature and relative humidity values registered daily at $30 \mathrm{~min}$ intervals in Lisbon and Oxford from November 2005 until November 2006.

\subsection{Loading fixture}

The tests were performed in specifically designed loading fixtures. The loading fixtures were created with the objective of testing several replicates at the same time, using the minimum possible amount of materials (adherends and adhesives), the space occupied by the set up was to be as small as possible, and the minimal effort required for the deformation measurements during the ageing of the specimens. The rig developed consisted of a timber specimen (having a rectangular prism shape, measuring $80 \mathrm{~mm}$ in length, $80 \mathrm{~mm}$ in width and $10 \mathrm{~mm}$ in thickness, which derives from that described in the Standard Proposal CEN TC193/SC1/WG11 N48 [20]) bonded to a zinc plated threaded steel rod (having $10 \mathrm{~mm}$ in diameter) through a $2 \mathrm{~mm}$ thick bond-line (Fig. 1). The $2 \mathrm{~mm}$ bondline thickness (Fig. 1) was a compromise founded upon existing literature, practicality (not to thin) and preventing failure at the rod interface (not to thick).

The load was applied through a system comprising of a spring, two washers and a nut. The washer's shape centred the spring over the rod. The square and ground ends of the spring ensured that the axial force produced by the spring was transferred vertically to the timber. The compression spring was centred by the washer's groove (external washer groove matched the internal spring diameter). The washer adjacent to the timber had also a recess to allow for any deformation of the adhesive. The tension load applied to the rod corresponded roughly to $20 \%$ of pull-out strength, which corresponds to two or three times the load used in repair works, the latter varying between 6 and $10 \%$ of the pull-out strength. The load was chosen in order to account for potential changes in use (e.g., leading to heavier floor loading) of the structure and to give a safe margin to the strength and durability estimations made through this method. In addition, it should be noted that the specimen geometry itself (short bond length of $10 \mathrm{~mm}$ ) induces an accelerated condition.

The magnitude of the stress relaxation observed after loading the bonded specimens was accounted for by measuring the distance from the top of the rod to the surface of the timber. The experiment described here will therefore be considered as a

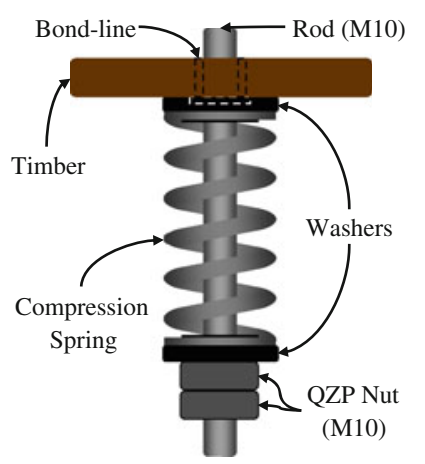

Fig. 1 Loading rig configuration and parts involved 
DOL experiment because the typical deformations observed in the specimens during weathering result in a decrease in the applied load, although less than 5\% of the initial value. Thus, the term creep used herein actually refers to the displacement observed between the rod and the timber during ageing. The decision to carry out a DOL experiment instead of a creep experiment was due to the impossibility of equipping each test specimen with a fixed load and a measuring device, e.g. LVDT, which would continuously record the displacement of the rod in respect to the timber.

\subsection{Specimen preparation}

Two timbers were used, namely, maritime pine (Pinus pinaster Ait.) and European oak (Quercus robur L.). These species constitute the most common wood species used in Portugal and in the United Kingdom for the structural timber frames used in construction, where the repair/reinforcement techniques involving these structural adhesives are normally used. The adhesives used in this study were both commercial 2-component structural epoxy adhesives (Table 3). More details about the chemical composition of the adhesives can be found in [1].

Due to the large number of tests needed, it was decided to use only 10 replicates in each test. The timber selection was performed in a way that the timber's natural variability was distributed uniformly between all 56 batches used for the durability tests, thus producing an acceptable standard deviation replicated in a systematic way throughout the batches.

The initial timber selection involved eliminating the planks containing strength-reducing defects (such as knots, slope of grain, bark, resin pockets, etc.), for a minimum of $15 \mathrm{~mm}$ away from the surface to be bonded. The planks were cut in the transversal direction so that the bonded-in rod was bonded along the grain. The oak timber was bought as 1 meter long strips with a cross-section of $80 \times 80 \mathrm{~mm}^{2}$, and just needed to be cut in slices $10 \mathrm{~mm}$ thick. The maritime pine was not available, in an affordable way, with that cross-section, so thinner planks were obtained and then bonded with a PRF adhesive (KOMARTEX B/E70 from Colquímica - Indústria Nacional de Colas S.A.), allowed to cure at $20^{\circ} \mathrm{C}-65 \%$ rh for 1 month and then cut to the final cross-section dimensions. The specimens then cut from the boards and their density was determined. Pine specimens with heartwood within the bond area were eliminated, the grain orientation was checked for consistency, the grain slope was kept as straight as possible, and were then grouped to see how many specimens could be used from each board. Finally, they were distributed uniformly to form 56 groups of 10 specimens for pine and 46 groups of 10 specimens for oak.

To assemble the timber specimens with the bonded-in rod, a special jig was developed to ensure that the rod was bonded as perpendicular as possible with respect to the timber, and also to allow the assembly of several specimens at the same time in a reproducible manner.

Steel specimens (made to assess the adhesives' shear strength in a configuration identical to that of the timber specimens) were grit blasted (using a Vacublast International, model Ventus $72 \mathrm{~S}$ with pink 180/220 grit) approximately $30 \mathrm{~min}$ prior to bonding.

All bonded specimens were cured at $20^{\circ} \mathrm{C}-65 \% \mathrm{rh}$ for 2 months before being loaded. Figure 2 depicts the loading procedure.

In order to apply the desired load, two different techniques were tested. First, a dynamometric wrench with an adjustable torque was used to apply the load, but it was found that it had very poor reproducibility. Therefore, it was decided to use the spring rate

Table 3 Specifications of the adhesives evaluated

\begin{tabular}{|c|c|c|c|c|c|c|}
\hline Product & $\begin{array}{l}\text { Working } \\
\text { life }^{\mathrm{a}}\end{array}$ & $\begin{array}{l}\text { Cure } \\
\text { schedule }^{a}\end{array}$ & $\begin{array}{l}\text { Compressive } \\
\text { strength }(\mathrm{MPa})^{\mathrm{a}}\end{array}$ & $\begin{array}{l}\text { Shear strength } \\
(\mathrm{MPa})^{\mathrm{b}}\end{array}$ & $\begin{array}{l}\text { Tensile strength } \\
(\mathrm{MPa})^{\mathrm{b}}\end{array}$ & $\begin{array}{l}\text { Modulus of } \\
\text { elasticity }(\mathrm{GPa})^{\mathrm{b}}\end{array}$ \\
\hline \multirow[t]{3}{*}{ A } & $12 \mathrm{~h}-10^{\circ} \mathrm{C}$ & 3 days $-10^{\circ} \mathrm{C}$ & 55 & 36.4 & 31.6 & 2.3 \\
\hline & $6 \mathrm{~h}-20^{\circ} \mathrm{C}$ & 2 days $-20^{\circ} \mathrm{C}$ & & & & \\
\hline & $6 \mathrm{~h}-30^{\circ} \mathrm{C}$ & 1 day $-30^{\circ} \mathrm{C}$ & & & & \\
\hline B & $30 \min -25^{\circ} \mathrm{C}$ & - & 80 & 48.8 & 36.6 & 9.8 \\
\hline
\end{tabular}

\footnotetext{
${ }^{a}$ Values taken from the manufacturer material data sheet
}

b Values taken from [1] 


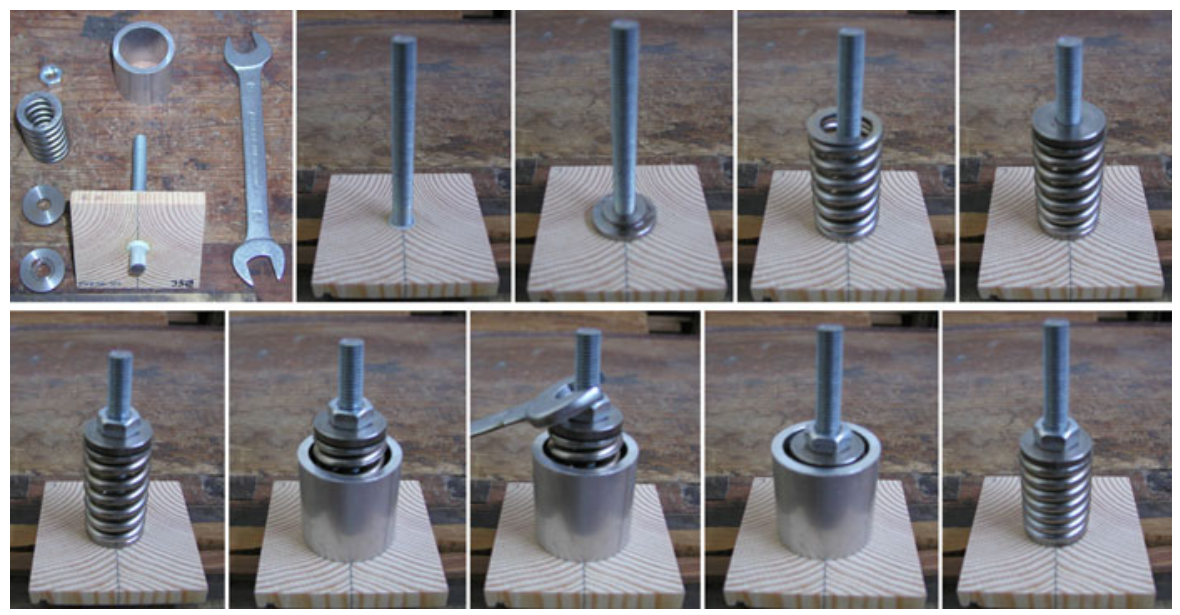

Fig. 2 Several stages involved in the specimens' preparation

(change in load per unit deflection, in Newtons per millimetre) to determine by how far the spring should be compressed to obtain the desired load $(\sim 1200 \mathrm{~N})$. The spring rate given by the manufacturer $(88.39 \mathrm{~N} /$ $\mathrm{mm}$ ) was confirmed by testing 10 springs in compression. From the results, it was observed that the spring rate was not linear. Because of that, it was decided to use the compressed length that corresponded to $1,200 \mathrm{~N}(13.8 \mathrm{~mm})$ in the tests. Thus, an aluminium ring was cut to the desired length (13.8 $\mathrm{mm}+$ washers' base thickness) and used as a guide to compress the springs to the correct load.

\subsection{Specimen weathering}

The natural weathering tests were carried out at LNEC and at OBU. Two sheds were built to accommodate the testing. At LNEC, the shed was orientated so that the door faced north. This allows all the specimens inside the shed to be located on the south wall, thus receiving approximately the same heat. The specimens were placed in racks with holes so that they were supported only by the timber, and the rod and adhesive were not in direct contact with the metal shelving, thus preventing excessive heat transmission. To improve the ventilation in the shed, the original Perspex windows (east and west façades) were replaced with a plastic mesh, and openings were cut in the north and south wall. To avoid the specimens' direct exposure to sunlight and rain, the metal structures placed in front of the windows inside the shed were covered with blackout fabric, which at the same time directed the air to the specimens in the south wall. At OBU, the only location offered was the building roof-top of the School of Technology. Similarly, openings were made in the shed to improve air circulation and avoid overheating.

The artificial accelerated weathering was performed at OBU using a Fisons environmental cabinet (Fisher Scientific UK Ltd., Loughborough, England-formerly Fisons Ltd.). A HOBO U12 Temperature/Relative Humidity Data Logger was used to record temperature and relative humidity in all weathering tests.

\subsection{Specimen testing}

The test that was developed to assess the long-term durability of bonded timber joints involved the periodical evaluation of deformation and RBS. The latter is determined by two types of tests, pull-out tests on the bonded specimens, and push-through tests on the solid timber specimens. The deformation measurement is explained below.

\subsubsection{Pull-out tests}

As these tests were performed in both countries, the experimental set-up developed in each country was as similar as reasonably possible. At LNEC an Instron ${ }^{\circledR}$ 4483 universal testing equipment with the Bluehill ${ }^{\circledR}$ Software was used to record load and cross-head displacement. The test set-up comprised of a metal cage with an $18 \mathrm{~mm}$ diameter hole, an aluminium 
alignment cylinder, a calibrated Linear Variable Differential Transformer (LVDT) displacement transducer (RDP DCTH500) connected to a Modular 600 Multi-Channel Signal Conditioning System. For the test, a $100 \mathrm{kN}$ load cell was used and a test speed of $1 \mathrm{~mm} / \mathrm{min}$ was applied following the recommendations made in $[15,17,24]$.

At OBU a Nene tensile/compression tester was used. The test set up comprised of a metal cage with an $18 \mathrm{~mm}$ diameter hole, an aluminium alignment cylinder and a LVDT displacement transducer (Solartron Metrology Gauging Transducer AX/2.5/S 540002-003). For the testing, a $25 \mathrm{kN}$ load cell and a test speed of $1 \mathrm{~mm} / \mathrm{min}$ were used.

\subsubsection{Push-through tests}

In order to test the solid timber control specimens a simple push-through test was developed. It consisted of pushing a flat top rod $(\varnothing 14 \mathrm{~mm})$ through the specimen, sitting on a metal cage with an $18 \mathrm{~mm}$ diameter hole, with a speed of $1 \mathrm{~mm} / \mathrm{min}$ until it failed. The failure load was recorded for each specimen. All specimens were conditioned at $20^{\circ} \mathrm{C}$ and $65 \%$ rh up to the moment they were tested. The tests were performed at $20^{\circ} \mathrm{C}$.

\subsubsection{Deformation measurements}

The periodical evaluation of the deformation was made with two systems. At LNEC it was measured with a height gauge (Mitutoyo Digimatic Indicator with Absolute encoder, ANSI/ADG 575-123, accuracy of $\pm 0.02 \mathrm{~mm}$ ). At $\mathrm{OBU}$ it was measured with a similar system, differing only in that the device, comprising a calliper (Chronos XC230 Electronic
Digital Calliper, accuracy of $\pm 0.02 \mathrm{~mm}$ ) was attached to the support, which was movable and was placed on top of each specimen.

\section{Results and discussion}

\subsection{Artificial accelerated weathering cycle}

From the weather data analysis performed it was observed that, over the 9-year period studied, the daily average temperature and relative humidity variation in both countries followed a yearly sinusoidal behaviour (Figs. 3, 4).

It follows that the temperature and relative humidity of the artificial accelerated cycle should exhibit a similar trend. Moreover, it was observed that there were periods of high temperatures accompanied by low relative humidities, of low temperatures accompanied by high relative humidities, and periods of intermediate temperature accompanied by intermediate relative humidity. Thus, the artificial accelerated weathering cycle should include periods of dry heat, damp cold and intermediate temperature and relative humidity.

Having decided upon the cycle shape, the temperature and relative humidities were determined, bearing in mind the need to use realistic temperatures and relative humidities as well as their daily amplitudes, so that they reflected the real service conditions to which this kind of joint is exposed to in practice.

From the weather data analysis performed it was observed that, over the 9-year period studied, the maximum, average and minimum temperatures registered were $43,17.1$ and $0^{\circ} \mathrm{C}$ for Lisbon, respectively, and $37,11.8$ and $-6^{\circ} \mathrm{C}$ for London, respectively. The
Fig. 3 Daily average temperatures recorded in Lisbon (Portugal) and London (UK)

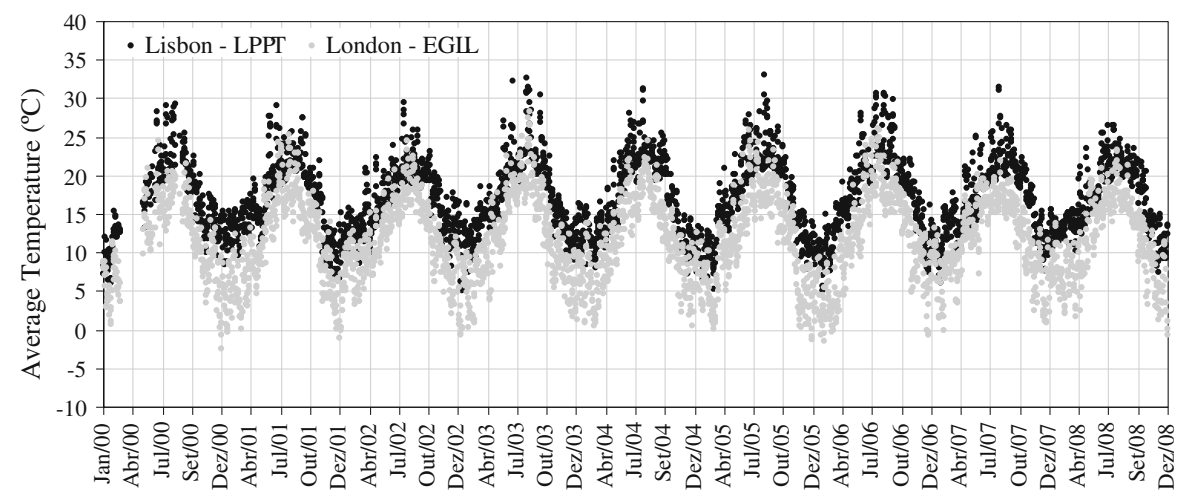


Fig. 4 Daily average relative humidities recorded in Lisbon (Portugal) and London (UK)

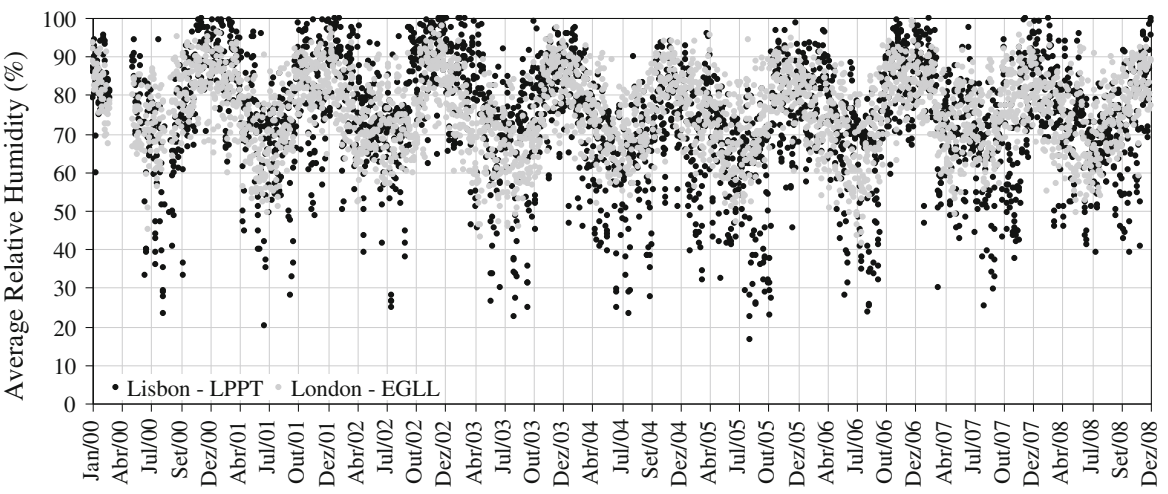

Table 4 Maximum, minimum and average temperatures and relative humidities registered in Lisbon and London

\begin{tabular}{|c|c|c|c|c|c|c|c|c|c|c|c|c|}
\hline \multirow[t]{3}{*}{ Year } & \multicolumn{6}{|c|}{ Lisbon, Portugal (LPPT) } & \multicolumn{6}{|c|}{ London, UK (EGLL) } \\
\hline & \multicolumn{3}{|c|}{ Temperature $\left({ }^{\circ} \mathrm{C}\right)$} & \multicolumn{3}{|c|}{ R. H. (\%rh) } & \multicolumn{3}{|c|}{ Temperature $\left({ }^{\circ} \mathrm{C}\right)$} & \multicolumn{3}{|c|}{ R. H. (\%rh) } \\
\hline & Max. & Min. & Avg. & Max. & Min. & Avg. & Max. & Min. & Avg. & Max. & Min. & Avg. \\
\hline 2000 & 37.0 & 2.0 & 17.0 & 100.0 & 10.0 & 76.5 & 31.0 & -5.0 & 11.7 & 100.0 & 13.0 & 78.7 \\
\hline 2001 & 36.0 & 3.0 & 16.8 & 100.0 & 10.0 & 77.0 & 32.0 & -5.0 & 11.1 & 100.0 & 26.0 & 76.9 \\
\hline 2002 & 37.0 & 4.0 & 16.9 & 100.0 & 6.0 & 79.7 & 32.0 & -1.0 & 12.2 & 100.0 & 22.0 & 76.3 \\
\hline 2003 & 43.0 & 1.0 & 17.2 & 100.0 & 6.0 & 75.3 & 37.0 & -5.0 & 12.0 & 100.0 & 15.0 & 72.0 \\
\hline 2004 & 39.0 & 3.0 & 17.4 & 100.0 & 7.0 & 68.4 & 30.0 & -5.0 & 11.7 & 100.0 & 19.0 & 76.3 \\
\hline 2005 & 40.0 & 0.0 & 17.0 & 100.0 & 4.0 & 66.9 & 33.0 & -5.0 & 11.9 & 100.0 & 24.0 & 74.4 \\
\hline 2006 & 39.0 & 1.0 & 17.5 & 100.0 & 10.0 & 73.9 & 35.0 & -6.0 & 12.1 & 100.0 & 13.0 & 74.5 \\
\hline 2007 & 40.0 & 3.0 & 17.0 & 100.0 & 4.0 & 71.1 & 28.0 & -5.0 & 11.9 & 100.0 & 15.0 & 75.6 \\
\hline 2008 & 37.0 & 0.0 & 16.8 & 100.0 & 9.0 & 73.6 & 30.0 & -4.0 & 11.4 & 100.0 & 19.0 & 74.8 \\
\hline Avg. & 38.7 & 1.9 & 17.1 & 100 & 7.3 & 73.6 & 32.0 & -4.6 & 11.8 & 100 & 18.4 & 75.5 \\
\hline
\end{tabular}

maximum, average and minimum relative humidities were 100, 73.6 and $4.0 \%$ in Lisbon, respectively, and 100, 75.5 and $13 \%$ in London, respectively (Table 4). In addition, in the same period, the maximum, average and minimum temperatures in Lisbon were 6.7, 5.3 and $6.4^{\circ} \mathrm{C}$ higher than in London, respectively, and the maximum, average and minimum relative humidities were $0,1.9$ and 11.1 lower in Lisbon than in London, respectively (Table 5). Notably, the average daily variation amplitudes of temperature and relative humidity were higher in Lisbon by only $0.5^{\circ} \mathrm{C}$ and $0.5 \%$ respectively (Table 6 ).

Over the period studied, the average temperature registered inside the roof in Lisbon was higher compared to that recorded outside (Table 7). On a hot day it was seen that the maximum, minimum and average temperatures registered inside were, respectively, 5.7, 1.1 and $2.2^{\circ} \mathrm{C}$ higher than outside, while on a cold day, the maximum, minimum and average temperatures registered inside were, respectively, 0.9, 0.7 and $0.1^{\circ} \mathrm{C}$ higher than outside. With these values in mind, it would be reasonable to assume that on a hot day, like the one observed in $01 / 08 / 2003$ when the maximum temperature reached $43^{\circ} \mathrm{C}$ outside, the temperature in the studied roof system would have been around $49^{\circ} \mathrm{C}$. The average relative humidity registered inside the roof cover in Lisbon was lower compared to that recorded outside (Table 8).

Over the period studied, the average temperature registered inside the roof in Oxford was higher than the one recorded outside (Table 9). On a hot day it was seen that the maximum, minimum and average temperatures registered inside were 10.8, 6.0 and $7.6^{\circ} \mathrm{C}$ higher than outside, respectively, while on a cold day, they were, 5.7, 7.3 and $6.3^{\circ} \mathrm{C}$ higher than outside, respectively. With these values in mind, it 
Table 5 Differences between temperatures and relative humidities attained in Lisbon and London

\begin{tabular}{|c|c|c|c|c|c|c|}
\hline \multirow[t]{3}{*}{ Year } & \multicolumn{6}{|c|}{$\Delta$ (Lisbon-London $)$} \\
\hline & \multicolumn{3}{|c|}{$\Delta$ Temperature $\left({ }^{\circ} \mathrm{C}\right)$} & \multicolumn{3}{|c|}{$\Delta$ R. H. (\%rh) } \\
\hline & Max. & Min. & Avg. & Max. & Min. & Avg. \\
\hline 2000 & 6 & 7 & 5 & 0 & -3 & -2 \\
\hline 2001 & 4 & 8 & 6 & 0 & -16 & 0 \\
\hline 2002 & 5 & 5 & 5 & 0 & -16 & 3 \\
\hline 2003 & 6 & 6 & 5 & 0 & -9 & 3 \\
\hline 2004 & 9 & 8 & 6 & 0 & -12 & -8 \\
\hline 2005 & 7 & 5 & 5 & 0 & -20 & -8 \\
\hline 2006 & 4 & 7 & 5 & 0 & -3 & -1 \\
\hline 2007 & 12 & 8 & 5 & 0 & -11 & -5 \\
\hline 2008 & 7 & 4 & 5 & 0 & -10 & -1 \\
\hline Avg. & 6.7 & 6.4 & 5.3 & 0.0 & -11.1 & -1.9 \\
\hline
\end{tabular}

Table 6 Temperatures and relative humidities amplitudes observed in Lisbon and London

\begin{tabular}{llllll}
\hline Year & \multicolumn{2}{l}{ Lisbon (LPPT) } & & \multicolumn{2}{l}{ London (EGLL) } \\
\cline { 2 - 3 } \cline { 5 - 6 } \cline { 5 - 6 } & $\uparrow T\left({ }^{\circ} \mathrm{C}\right)$ & $\uparrow$ R. H. (\%rh) & & $\uparrow\left({ }^{\circ} \mathrm{C}\right)$ & $\uparrow$ R. H. (\%rh) \\
\hline 2000 & 8 & 37 & 7 & 33 \\
2001 & 8 & 36 & 7 & 35 \\
2002 & 8 & 37 & 7 & 36 \\
2003 & 8 & 39 & 8 & 40 \\
2004 & 8 & 40 & 7 & 36 \\
2005 & 8 & 40 & 7 & 36 \\
2006 & 8 & 37 & 8 & 41 \\
2007 & 8 & 39 & 8 & 42 \\
2008 & 8 & 39 & 7 & 40 \\
Avg. & 7.9 & 38.2 & 7.4 & 37.7 \\
\hline
\end{tabular}

would be reasonable to assume that on a hot day, like the one observed in 10/08/2003, when the maximum temperature reached $37^{\circ} \mathrm{C}$ outside, the temperature in the studied roof system could have reached $48^{\circ} \mathrm{C}$. The average relative humidity registered inside the roof cover in Oxford was lower than the one recorded outside with the exception of the average minimum values (Table 10).

Considering the daily amplitudes observed in both countries (Table 11), the temperature amplitudes for the roof systems in Lisbon and Oxford were quite similar $\left(9.4^{\circ} \mathrm{C}\right)$. Regarding the relative humidity, the differences between the roof systems were more pronounced, with the roof systems in Oxford presenting a much greater variation from the relative humidity registered outside ( $-9.4 \%$ for PT and $-27.5 \%$ for UK).

In spite of the higher temperatures attained in Portugal, it can be concluded that the timber elements present in the roof systems in both countries may be subjected to high temperatures, in the order of $48-49^{\circ} \mathrm{C}$ or more, since Lisbon and Oxford are not located in the hottest regions in their respective countries. Thus, it is important to understand the thermal sensitivity of the adhesive systems used to repair/reinforce timber elements in roof systems.

From these observations, the artificially accelerated weathering cycle presented in Table 12 was created. The cycle consists of two consecutive hot periods (parts $\mathrm{A}-\mathrm{B}$ and $\mathrm{C}-\mathrm{D}$ ) and two cold periods (parts $\mathrm{F}-\mathrm{G}$ and $\mathrm{H}-\mathrm{I}$ ) separated by a mild period (parts $\mathrm{E}$ and $\mathrm{J}$ ).

The temperature chosen for the lower limit of the hot period and the top limit of the cold period was $17^{\circ} \mathrm{C}$. This value corresponds to the average daily

Table 7 Maximum, minimum and average temperatures and relative humidities registered in Lisbon (exterior and roof)

\begin{tabular}{|c|c|c|c|c|c|c|c|c|c|c|c|c|}
\hline & \multicolumn{6}{|c|}{ Exterior daily values (Lisbon, Portugal) } & \multicolumn{6}{|c|}{ Interior daily values (Lisbon, Portugal) } \\
\hline & \multicolumn{3}{|c|}{ Temperature $\left({ }^{\circ} \mathrm{C}\right)$} & \multicolumn{3}{|c|}{ R. H. (\%rh) } & \multicolumn{3}{|c|}{ Temperature $\left({ }^{\circ} \mathrm{C}\right)$} & \multicolumn{3}{|c|}{ R. H. (\%rh) } \\
\hline & Max. & Min. & Avg. & Max. & Min. & Avg. & Max. & Min. & Avg. & Max. & Min. & Avg. \\
\hline Avg. & 21.0 & 13.5 & 16.8 & 91.2 & 54.6 & 74.8 & 23.5 & 14.1 & 17.9 & 77.7 & 50.5 & 65.7 \\
\hline Max. & 39.0 & 26.0 & 30.7 & 100 & 100 & 100.0 & 42.7 & 27.1 & 32.7 & 96.4 & 91.5 & 93.3 \\
\hline Min. & 7.0 & 1.0 & 5.2 & 39 & 9 & 23.8 & 7.9 & 1.7 & 4.7 & 40.6 & 14.4 & 26.7 \\
\hline HD & 37.0 & 25.0 & 30.4 & 57 & 20 & 38.2 & 42.7 & 26.1 & 32.7 & 52.3 & 20.4 & 35.9 \\
\hline CD & 7.0 & 1.0 & 5.1 & 100 & 70 & 85.5 & 7.9 & 1.7 & 5.2 & 91.8 & 70.5 & 79.4 \\
\hline
\end{tabular}

Notes: Avg. average of values obtained with 30 min intervals recorded from 21/10/2005 until 01/10/2008 in Lisbon; Max. maximum values obtained in that time frame; Min. minimum values obtained the same time frame; HD values obtained on a hot day (15/07/ 2006); $C D$ values obtained on a cold day (29/01/2006) 
Table 8 Temperature and relative humidity differences between interior and exterior in Lisbon

\begin{tabular}{llllllll}
\hline & \multicolumn{4}{l}{$\Delta$ Lisbon daily values (Interior-Exterior) } \\
\cline { 2 - 3 } & \multicolumn{2}{l}{$\Delta$ Temperature $\left({ }^{\circ} \mathrm{C}\right)$} & & \multicolumn{2}{c}{$\Delta$ R. H. (\%rh) } \\
\cline { 2 - 3 } \cline { 5 - 7 } & Max. & Min. & Avg. & & Max. & Min. & Avg. \\
\hline Avg. & 2.5 & 0.6 & 1.1 & & -13.5 & -4.1 & -9.1 \\
HD & 5.7 & 1.1 & 2.3 & & -4.7 & 0.4 & -2.3 \\
CD & 0.9 & 0.7 & 0.1 & & -8.2 & 0.5 & -6 \\
\hline
\end{tabular}

Notes: Avg. difference between averages of values obtained with 30 min intervals recorded from 21/10/2005 until 01/10/ 2008 in Lisbon; $H D$ difference between values obtained on a hot day (15/07/2006); $C D$ difference between values obtained on a cold day (29/01/2006)

temperature registered outside in Lisbon over the 9-year period $\left(17 \cdot 1^{\circ} \mathrm{C}\right)$. Although, this value is somewhat higher than the average daily temperature registered outside in London $\left(11.8^{\circ} \mathrm{C}\right)$ in the same period, it is only slightly lower than the average daily temperature recorded inside both roof systems $\left(17.9^{\circ} \mathrm{C}\right.$ for PT and $17.5^{\circ} \mathrm{C}$ for UK) over the specific period studied. Besides, as ageing effects are generally more pronounced at higher temperatures, it is preferable to use the higher temperature.

The temperature selected for the top limit of the hot period was $50^{\circ} \mathrm{C}$. Over the 9-year period studied, the maximum temperature registered outside was $43^{\circ} \mathrm{C}$ for Lisbon and $37^{\circ} \mathrm{C}$ for London. During the course of this work, between 2005 and 2008, the maximum temperature registered in Lisbon was $39^{\circ} \mathrm{C}$ outside and $42.7^{\circ} \mathrm{C}$ inside. In Oxford, the maximum temperature registered was $40.1{ }^{\circ} \mathrm{C}$ outside and $46.8^{\circ} \mathrm{C}$ inside. Thus, $50^{\circ} \mathrm{C}$ is a realistic temperature
Table 10 Temperature and relative humidity differences between interior and exterior in Oxford

\begin{tabular}{|c|c|c|c|c|c|c|}
\hline & $\Delta \mathrm{Ox}$ & d daily & alues ( & erior-Ex & rior) & \\
\hline & $\Delta$ Ten & erature & & $\Delta \mathrm{R} . \mathrm{H}$ & \%rh) & \\
\hline & Max. & Min. & Avg. & Max. & Min. & Avg. \\
\hline Avg. & 4.5 & 5.4 & 5.4 & -23.4 & 5.8 & -10.8 \\
\hline HD & 10.8 & 6.0 & 7.6 & -26.7 & 2.6 & -11.7 \\
\hline CD & 5.7 & 7.3 & 6.3 & -20.3 & -8.8 & -16.0 \\
\hline
\end{tabular}

Notes: Avg. difference between averages of values obtained with 30 min intervals recorded from 18/10/2005 until 18/09/ 2008 in Oxford; $H D$ values obtained on a hot day (19/07/2006); $C D$ values obtained on a cold day $(28 / 12 / 2005)$

Table 11 Temperature and relative humidity amplitudes observed in Lisbon and Oxford

\begin{tabular}{llllll}
\hline $\begin{array}{l}\text { Daily } \\
\text { amplitudes }\end{array}$ & \multicolumn{2}{l}{ Lisbon (Portugal) } & & \multicolumn{2}{l}{ Oxford (UK) } \\
\cline { 2 - 3 } \cline { 5 - 6 } & $\uparrow T\left({ }^{\circ} \mathrm{C}\right)$ & $\begin{array}{c}\uparrow \mathrm{R} . \mathrm{H} . \\
(\% \mathrm{rh})\end{array}$ & & $\uparrow T\left({ }^{\circ} \mathrm{C}\right)$ & $\begin{array}{l}\uparrow \mathrm{R} . \mathrm{H} . \\
(\% \mathrm{rh})\end{array}$ \\
\hline Outside & 7.5 & 36.6 & & 10.3 & 41.6 \\
Inside & 9.4 & 27.2 & & 9.4 & 12.4 \\
Difference & 1.9 & -9.4 & & -0.9 & -27.5 \\
\hline
\end{tabular}

to be reached in a roof system, especially since Lisbon and London are not the hottest locations in both countries.

For the cold period, a lower limit of $10^{\circ} \mathrm{C}$ was elected considering the average daily temperature and relative humidity amplitude variation in Lisbon and London, $\sim 7$ to $8^{\circ} \mathrm{C}$, and the top limit for the cold cycle $\left(17^{\circ} \mathrm{C}\right)$. This value also lies between the average temperatures registered in the winter in Lisbon $\left(11.8^{\circ} \mathrm{C}\right)$ and in London $\left(6.1^{\circ} \mathrm{C}\right)$.

Table 9 Maximum, minimum and average temperatures and relative humidities registered in Oxford (exterior and roof)

\begin{tabular}{|c|c|c|c|c|c|c|c|c|c|c|c|c|}
\hline & \multicolumn{6}{|c|}{ Exterior daily values (Oxford, UK) } & \multicolumn{6}{|c|}{ Interior daily values (Oxford, UK) } \\
\hline & \multicolumn{3}{|c|}{ Temperature $\left({ }^{\circ} \mathrm{C}\right)$} & \multicolumn{3}{|c|}{ R. H. (\%rh) } & \multicolumn{3}{|c|}{ Temperature $\left({ }^{\circ} \mathrm{C}\right)$} & \multicolumn{3}{|c|}{ R. H. (\%rh) } \\
\hline & Max. & Min. & Avg. & Max. & Min. & Avg. & Max. & Min. & Avg. & Max. & Min. & Avg \\
\hline Avg. & 18.1 & 7.8 & 12.1 & 89.9 & 48.3 & 71.2 & 22.6 & 13.2 & 17.5 & 66.5 & 54.1 & 60.4 \\
\hline Max. & 40.1 & 25.6 & 27.7 & 98.0 & 98.0 & 98.0 & 46.8 & 27.6 & 36.1 & 96.0 & 87.4 & 87.9 \\
\hline Min. & 1.6 & -6.0 & -0.6 & 47.0 & 15.0 & 32.1 & 7.3 & 1.2 & 5.7 & 41.3 & 22.6 & 32.5 \\
\hline HD & 36.0 & 18.8 & 27.7 & 68.0 & 20.0 & 44.2 & 46.8 & 24.8 & 35.3 & 41.3 & 22.6 & 32.5 \\
\hline $\mathrm{CD}$ & 2.0 & -3.3 & -0.6 & 92.0 & 76.0 & 84.6 & 7.7 & 4.0 & 5.7 & 71.7 & 67.2 & 68.6 \\
\hline
\end{tabular}

Notes: Avg. average of values obtained with 30 min intervals recorded from 18/10/2005 until 18/09/2008 in Oxford; Max. maximum values obtained in that time frame; Min. minimum values obtained the same time frame; $H D$ values obtained on a hot day (19/07/ 2006); $C D$ values obtained on a cold day (28/12/2005) 
Table 12 Artificial accelerated weathering cycle

\begin{tabular}{lllll}
\hline Part & $\begin{array}{l}\text { Duration } \\
(\mathrm{h})\end{array}$ & $\begin{array}{l}\text { Temperature } \\
\left({ }^{\circ} \mathrm{C}\right)\end{array}$ & $\begin{array}{l}\text { Relative } \\
\text { humidity } \\
(\%)\end{array}$ & $\begin{array}{l}\text { Timber } \\
\text { moisture } \\
\text { content } \\
\text { attained }(\%)\end{array}$ \\
\hline A & 48 & $17 \pm 2$ & $95 \pm 5$ & $17-18$ \\
B & 24 & $50 \pm 2$ & $40 \pm 5$ & $9-10$ \\
C & 48 & $17 \pm 2$ & $95 \pm 5$ & $17-18$ \\
D & 24 & $50 \pm 2$ & $40 \pm 5$ & $9-10$ \\
E & 24 & $20 \pm 2$ & $65 \pm 5$ & $11-12$ \\
F & 48 & $17 \pm 2$ & $95 \pm 5$ & $17-18$ \\
G & 24 & $10 \pm 2$ & $95 \pm 5$ & $18-19$ \\
H & 48 & $17 \pm 2$ & $95 \pm 5$ & $19-20$ \\
I & 24 & $10 \pm 2$ & $95 \pm 5$ & $20-21$ \\
J & 24 & $20 \pm 2$ & $65 \pm 5$ & - \\
\hline
\end{tabular}

The conditions for the mild period were chosen to be $20^{\circ} \mathrm{C}$ and $65 \% \mathrm{rh}$, which correspond to the conditions to which the specimens had been stabilized prior to testing. This value is also close to the average relative humidities recorded inside both roof structures (65.7\% for Lisbon and $60.4 \%$ for Oxford). Furthermore, this period is imperative since it allows some dimensional and moisture content recovery, consequently, reducing the swelling strain of wood at the bond-line, as would be expected under real conditions.

In order to decide which relative humidity should be used at $17^{\circ} \mathrm{C}$, it was decided to verify which relative humidities are normally observed with this kind of temperature. Thus, at $17^{\circ} \mathrm{C}$ Lisbon registered an average of $78 \%$ (varying from 13 to $100 \%$ ) and London $71 \%$ (varying from 18 to $100 \%$ ). Inside the roof covers, at $17^{\circ} \mathrm{C}$ Lisbon registered an average of $69 \%$ (varying from 27 to $96 \%$ ) and Oxford $62 \%$ (varying from 38 to $87 \%$ ). It was concluded that with this temperature, relatively high humidities may be observed, and so a value of 95\%rh was selected. Again, as ageing effects are expected to be more pronounced at higher humidities, it is preferable to use the higher values.

For the cool $10^{\circ} \mathrm{C}$ periods it was decided to use the same $95 \%$ relative humidity, based upon values observed in the field that were similar to the one observed at $17^{\circ} \mathrm{C}$. Thus, Lisbon registered an average of $84 \%$ (varying from 20 to $100 \%$ ) and London $80 \%$ (varying from 20 to $100 \%$ ). The roof in Lisbon registered an average of $76 \%$ (varying from 34 to
94\%) and the one in Oxford $71 \%$ (varying from 44 to $90 \%)$.

Concerning the hot period, it was important to verify the relative humidities achieved normally in the field during hot spells. For outside average temperatures between 30 and $43^{\circ} \mathrm{C}$ the average relative humidity was $27 \%$ for Lisbon (ranging from 0 to $55 \%$ ) and $34 \%$ in London (ranging from 13 to $51 \%$ ). For inside average temperatures between 30 and $47^{\circ} \mathrm{C}$ the average relative humidity was $33 \%$ in Lisbon (varying from 14 to $52 \%$ ) and $38 \%$ in Oxford (varying from 23 to $62 \%$ ). For inside temperatures of $40-47^{\circ} \mathrm{C}$ the relative humidity was $22 \%$ for Lisbon $(15-31 \%)$ and $31 \%$ for Oxford (23-43\%). From this, a relative humidity of $40 \%$ was chosen for parts B and D.

The newly developed weathering cycle should therefore be able to produce an accelerated ageing of the specimens in a more realistic manner, since it uses temperatures and relative humidities based on the data collected from field measurements. In summary, the duration of each period, the temperature and humidity amplitudes varying within not too short a transition times, the consecutive repetition of the hot and cold cycles, together with the specimen geometry ought to provide the desired accelerated ageing without the adverse effects highlighted earlier in existing accelerated tests. For locations where environmental service conditions differ significantly from the two presented above, a modified AAW cycle could be developed based on the methodology presented herein.

\subsection{Weathering conditions}

Figures 5, 6 and 7 exhibit the temperature and relative humidity to which the test specimens were subjected during weathering. It can be seen that the conditions experienced in Lisbon (Portugal) were, as expected, more severe than the ones registered in Oxford (UK), with Lisbon experiencing higher temperatures and relative humidities and larger daily fluctuations compared to London. In Lisbon, the highest temperature was $46.3^{\circ} \mathrm{C}$, whilst the minimum was $1.9^{\circ} \mathrm{C}$. In Oxford, in the same period, the highest temperature was only $28.8^{\circ} \mathrm{C}$, whilst the minimum was $-4.4^{\circ} \mathrm{C}$.

In the evaluated period, the artificial accelerated cycle registered an average temperature higher than 
Fig. 5 Temperature and relative humidity registered during the natural weathering in Lisbon

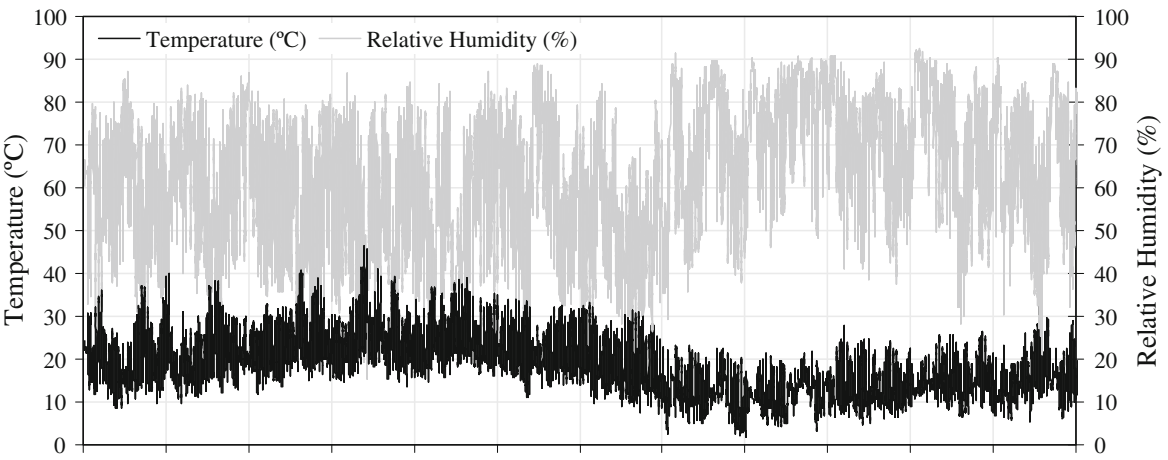

17/04/07 17/05/07 17/06/07 17/07/07 17/08/07 16/09/07 17/10/07 16/11/07 17/12/07 16/01/08 16/02/08 17/03/08 17/04/08
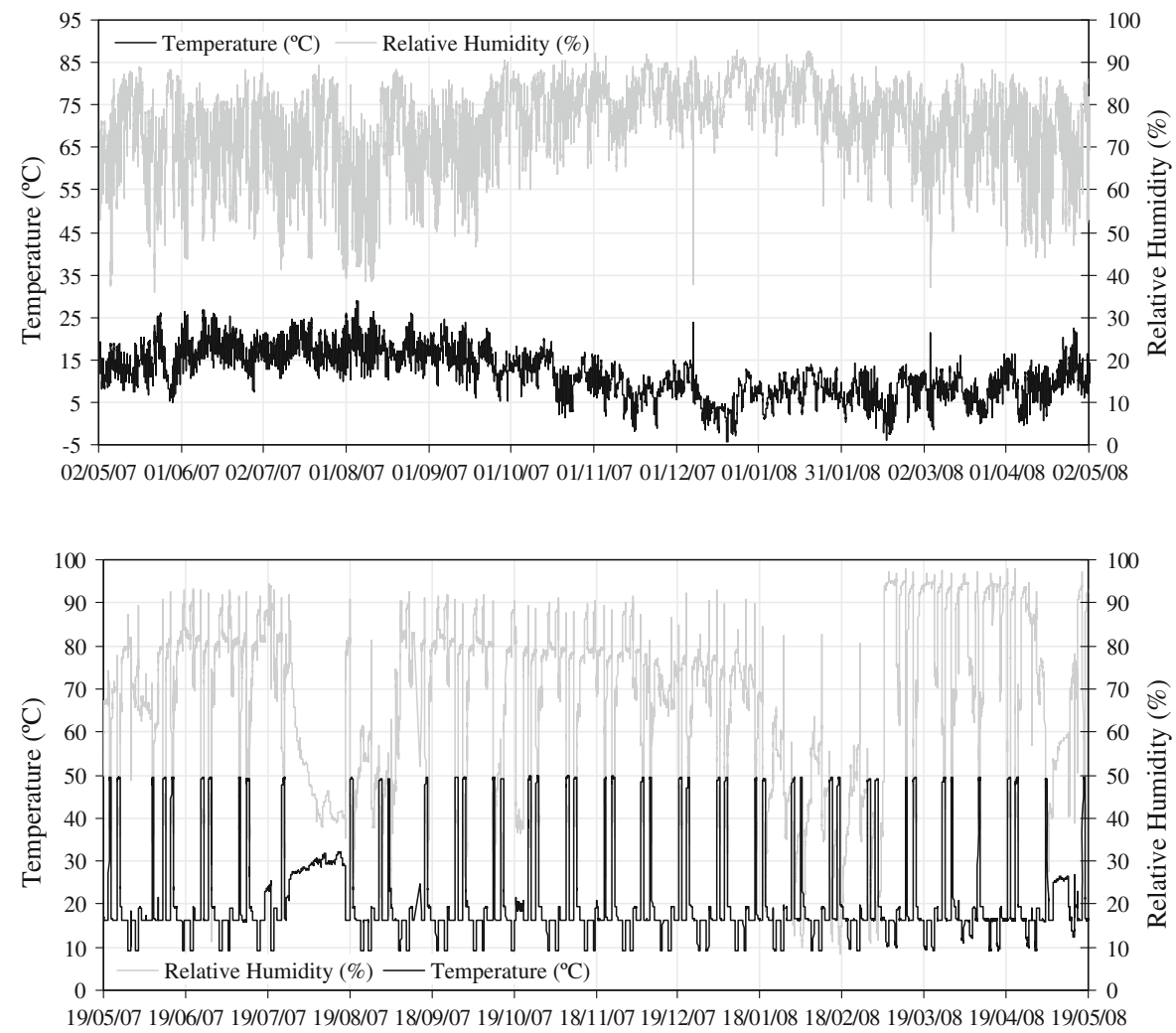

Fig. 7 Temperature and relative humidity registered during the AAW cycle
Fig. 6 Temperature and relative humidity registered during the natural weathering in Oxford 
Table 13 Maximum, minimum and average temperatures and relative humidities registered during weathering

\begin{tabular}{lrrrrrrr}
\hline & \multicolumn{2}{c}{ Temperature $\left({ }^{\circ} \mathrm{C}\right)$} & & \multicolumn{3}{c}{ Relative humidity $(\% \mathrm{rh})$} \\
\cline { 2 - 3 } \cline { 7 - 8 } \cline { 7 - 8 } & Max. & Min. & Avg. & & Max. & Min. & Avg. \\
\hline NW PT & 46.3 & 1.9 & 18.1 & & 92.4 & 15.4 & 62.9 \\
NW UK & 28.8 & -4.4 & 11.5 & & 93.0 & 35.9 & 74.9 \\
AAW & 49.8 & 9.1 & 21.3 & & 97.7 & 8.3 & 61.0 \\
\hline
\end{tabular}

Notes: NW PT natural weathering in Lisbon (Portugal); NW UK natural weathering in Oxford (UK); $A A W$ artificial accelerated weathering

Table 14 Temperature duration registered during weathering

\begin{tabular}{lccc}
\hline Temperature $\left({ }^{\circ} \mathrm{C}\right)$ & NW PT $(\mathrm{h})$ & NW UK (h) & AAW (h) \\
\hline$T \geq 40^{\circ} \mathrm{C}$ & 18 & 0 & 1,106 \\
$30^{\circ} \mathrm{C} \leq T<40^{\circ} \mathrm{C}$ & 576 & 0 & 175 \\
$20^{\circ} \mathrm{C} \leq T<30^{\circ} \mathrm{C}$ & 2,376 & 620 & 691 \\
$10^{\circ} \mathrm{C} \leq T<20^{\circ} \mathrm{C}$ & 4,852 & 4,595 & 6,751 \\
$T<10^{\circ} \mathrm{C}$ & 961 & 3,570 & 0 \\
\hline
\end{tabular}

Notes: NW PT natural weathering in Lisbon (Portugal); NW UK natural weathering in Oxford (UK); $A A W$ artificial accelerated weathering

Table 15 Relative humidity duration registered during weathering

\begin{tabular}{llll}
\hline Temperature $\left({ }^{\circ} \mathrm{C}\right)$ & NW PT $(\mathrm{h})$ & NW UK $(\mathrm{h})$ & AAW (h) \\
\hline $\mathrm{RH} \geq 80 \%$ & 1,347 & 3,244 & 2,421 \\
$65 \% \leq \mathrm{RH}<80 \%$ & 3,107 & 4,056 & 2,862 \\
$50 \% \leq \mathrm{RH}<65 \%$ & 2,168 & 1,285 & 1,083 \\
$25 \% \leq \mathrm{RH}<50 \%$ & 2,129 & 199 & 2,081 \\
$\mathrm{RH}<25 \%$ & 31 & 0 & 275 \\
\hline
\end{tabular}

Notes: NW PT natural weathering in Lisbon (Portugal); NW UK natural weathering in Oxford (UK); $A A W$ artificial accelerated weathering

Table 15 presents the relative humidity conditions to which the specimens were exposed during 12 months of weathering and demonstrates the very different characteristics of the natural weathering in Lisbon compared to Oxford. Over the 12 months weathering period, the artificially aged specimens were subjected to almost two times more hours of humidity above $80 \%$ and to almost two times less hours of humidity between 50 and $65 \%$. On the other hand, the naturally aged specimens in Lisbon and the artificially aged specimens were exposed to, approximately, the same duration of humidity between 65 and $80 \%$. During the 12 months of natural weathering in Oxford, the specimens were subjected to many more hours of humidity above $50 \%$, more specifically almost one and a half times more hours at humidities above $80 \%$ and between 65 and $80 \%$.

\subsection{Bonded joint performance}

The results presented here refer to the bonded timber specimens subjected to natural and artificially accelerated weathering having 12 months of ageing. Table 16 shows the pull-out and push-through strengths obtained and the number of specimens that failed during ageing. Table 17 shows the corresponding failure modes.

\subsubsection{Unaged bonded joints}

The timber specimens bonded with the more ductile adhesive (adhesive A) registered higher pull-out strengths (22.8 MPa for pine and 21.1 MPa for oak) than those obtained for the specimens bonded with the more brittle adhesive (adhesive B) (19.2 MPa for pine and 18.7 MPa for oak). This was in line with the findings from Feligioni et al. [25] who used maximum pull-out strength of threaded steel rods bonded into spruce specimens to investigate the relationship between the joint geometry and the rheology of the structural adhesive (testing a brittle and a ductile epoxy adhesive). The authors found that the adhesive rheology had a strong influence on the joint behaviour, with the ductile adhesive resulting in a stronger joint. Taking into account the failure modes, for the same timber species, higher pull-out strengths corresponded to larger percentages of cohesive wood failure and lower percentages of cohesive adhesive failure. This may also indicate that adhesive A produced better adhesion at the timber/adhesive interface than adhesive $\mathrm{B}$, due to the higher number of hydroxyl groups present in the adhesive using a polyoxypropyleneamine hardener or to better adhesive penetration in timber [1].

For either adhesive, pine and oak registered similar pull-out strengths, in spite of the pine timber having a $\sim 3 \mathrm{MPa}$ higher shear strength than that of the oak. This may be due to the fact that both adhesives appear to produce a better bond to oak than to pine, also reflected in the higher percentages of adhesion 
Table 16 Pull-out and push-through tests results

\begin{tabular}{|c|c|c|c|c|c|c|c|c|c|}
\hline \multirow[t]{2}{*}{ Weathering } & \multirow[t]{2}{*}{ Load } & \multirow[t]{2}{*}{ Adhesive } & \multirow[t]{2}{*}{ Country } & \multirow[t]{2}{*}{ Adherend } & \multicolumn{5}{|c|}{$\begin{array}{l}\text { Pull-out/push-through strength (MPa) at rod/adhesive } \\
\text { interface after ageing for }\end{array}$} \\
\hline & & & & & 0 months & 3 months & 6 months & 9 months & 12 months \\
\hline \multirow[t]{4}{*}{ None } & \multirow[t]{2}{*}{$\checkmark$} & \multirow[t]{2}{*}{ A } & \multirow[t]{2}{*}{-} & Pine & $22.8(1.2)$ & - & - & - & $20.7(0.9)$ \\
\hline & & & & Oak & $21.1(0.8)$ & - & - & - & $20.2(0.7)$ \\
\hline & \multirow[t]{2}{*}{$\checkmark$} & \multirow[t]{2}{*}{ B } & \multirow[t]{2}{*}{-} & Pine & $19.2(1.3)$ & - & - & - & $18.4(1.0)$ \\
\hline & & & & Oak & $18.7(0.7)$ & - & - & - & $16.3(1.2)$ \\
\hline \multirow[t]{20}{*}{ Natural } & \multirow[t]{4}{*}{$v$} & \multirow[t]{4}{*}{ A } & \multirow[t]{2}{*}{ UK } & Pine & $22.8(1.2)$ & - & $17.4(0.8)$ & - & $16.9(0.9)$ \\
\hline & & & & Oak & $21.1(0.8)$ & - & $18.9(0.5)$ & - & $19.0(0.5)$ \\
\hline & & & \multirow[t]{2}{*}{$\mathrm{PT}$} & Pine & $17.6(1.1)$ & $\mathrm{a}$ & $19.6(1.3)^{\mathrm{d}}$ & - & $15.8(1.3)$ \\
\hline & & & & Oak & $18.3(0.3)$ & $\mathrm{b}$ & $18.4(1.0)^{\mathrm{d}}$ & - & $18.1(0.5)$ \\
\hline & \multirow[t]{4}{*}{$\checkmark$} & \multirow[t]{4}{*}{$\mathrm{B}$} & \multirow[t]{2}{*}{$\mathrm{UK}$} & Pine & $19.2(1.3)$ & - & $17.5(0.9)$ & - & $16.8(0.6)$ \\
\hline & & & & Oak & $18.7(0.7)$ & - & $16.7(0.5)$ & - & $17.1(0.6)$ \\
\hline & & & \multirow[t]{2}{*}{$\mathrm{PT}$} & Pine & $16.9(1.1)$ & - & $18.2(1.0)$ & - & $17.5(1.0)$ \\
\hline & & & & Oak & $17.1(0.4)$ & - & $17.4(0.4)$ & - & $17.2(0.7)$ \\
\hline & \multirow[t]{4}{*}{$\times$} & \multirow[t]{4}{*}{ A } & \multirow[t]{2}{*}{ UK } & Pine & $22.8(1.2)$ & - & - & - & $20.1(0.9)$ \\
\hline & & & & Oak & $21.1(0.8)$ & - & - & - & $18.9(0.7)$ \\
\hline & & & \multirow[t]{2}{*}{$\mathrm{PT}$} & Pine & $17.6(1.1)$ & - & - & - & $19.7(1.2)$ \\
\hline & & & & Oak & $18.3(0.3)$ & - & - & - & $19.2(0.6)$ \\
\hline & \multirow[t]{4}{*}{$\times$} & \multirow[t]{4}{*}{ B } & \multirow[t]{2}{*}{ UK } & Pine & $19.2(1.3)$ & - & - & - & $17.8(1.0)$ \\
\hline & & & & Oak & $18.7(0.7)$ & - & - & - & $16.5(0.5)$ \\
\hline & & & \multirow[t]{2}{*}{$\mathrm{PT}$} & Pine & $16.9(1.1)$ & - & - & - & $17.6(1.2)$ \\
\hline & & & & Oak & $17.1(0.4)$ & - & - & - & $16.9(0.6)$ \\
\hline & $x$ & $x$ & UK & Pine & $16.4(0.6)$ & - & - & - & $17.3(1.0)$ \\
\hline & & & & Oak & $13.5(0.7)$ & - & - & - & $13.6(0.5)$ \\
\hline & & & $\mathrm{PT}$ & Pine & $16.4(1.6)$ & - & - & - & $17.1(1.0)$ \\
\hline & & & & Oak & $13.5(0.7)$ & - & - & - & $13.5(0.5)$ \\
\hline Artificial Accelerated & $\checkmark$ & A & - & Pine & $22.8(1.2)$ & c & - & - & - \\
\hline & $\checkmark$ & $\mathrm{B}$ & - & Pine & $19.2(1.3)$ & $17.1(0.8)$ & $16.7(1.0)$ & $14.2(1.8)$ & 0 \\
\hline & $\times$ & $\times$ & - & Pine & $13.8(0.6)$ & - & - & - & $15.1(0.7)$ \\
\hline
\end{tabular}

The standard deviation is presented between brackets. Timbers density: Pine $633 \pm 62 \mathrm{~kg} / \mathrm{m}^{3}$; Oak $659 \pm 34 \mathrm{~kg} / \mathrm{m}^{3}$

$P T$ Lisbon (Portugal); UK Oxford (UK)

a 32 out of 50 specimens failed after 3 months of natural weathering

b 8 out of 50 specimens failed after 3 months of natural weathering

c 40 out of 40 specimens failed after 1 week of artificial accelerated weathering

d The values presented only include the load of the specimens that survived the corresponding ageing period

failure to wood and adhesion failure at wood adhesive interface observed in the failed pine joints.

The steel bonded joints, tested to determine the apparent shear strength of the adhesives, indicated that adhesive B had a higher apparent shear strength (48.8 MPa) than adhesive A (36.4 MPa). Thus, the steel bonded joints, which failed cohesively in the adhesive, registered higher pull-out strengths than the timber bonded joints.

According to Volkersen's [26] shear lag analysis, the stress concentration factor $n$ is proportional to the square root of the ratio of the shear modulus, $G$, of the adhesive to the Young's modulus, $E$, of the adherend, i.e. 


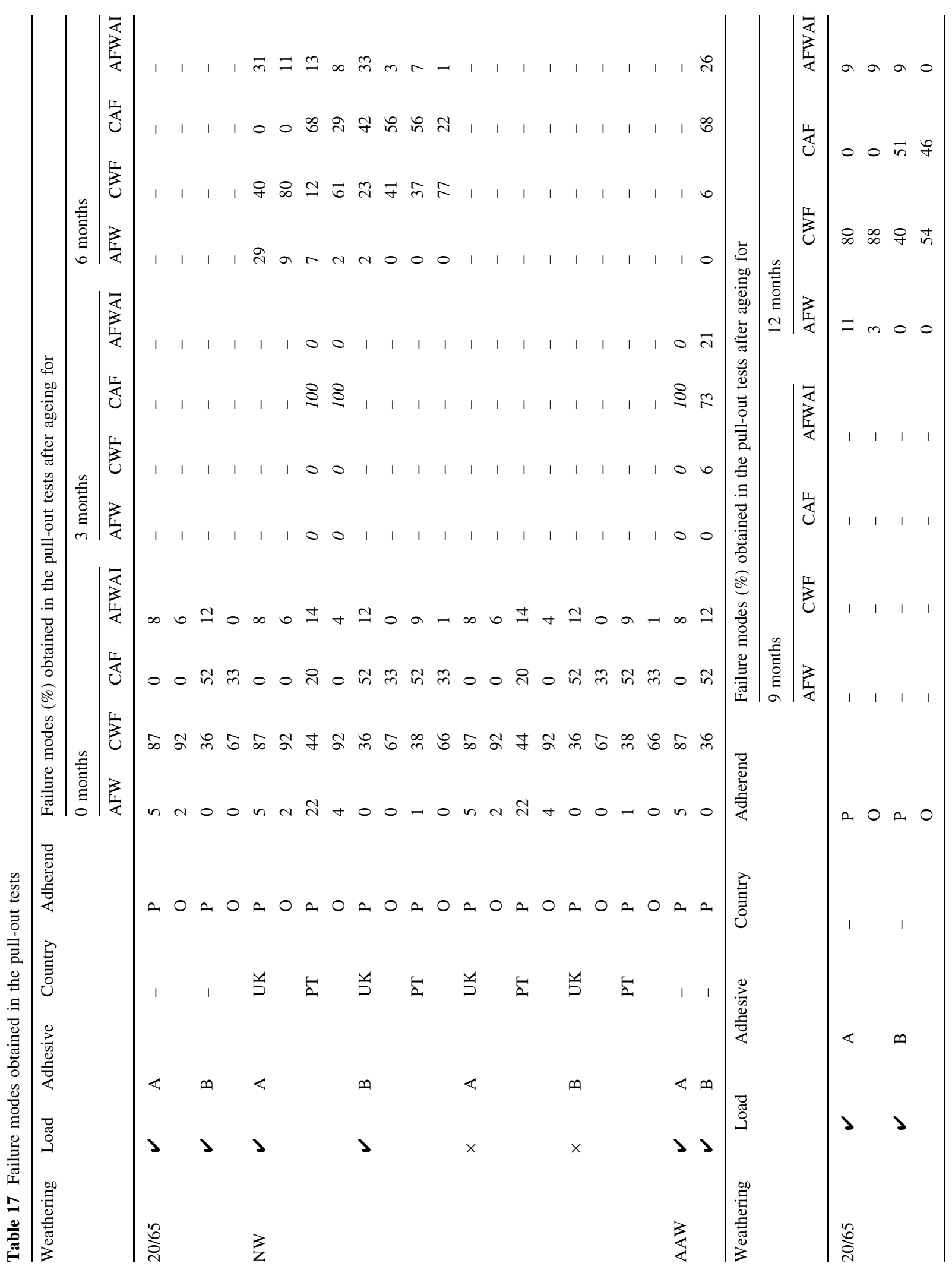




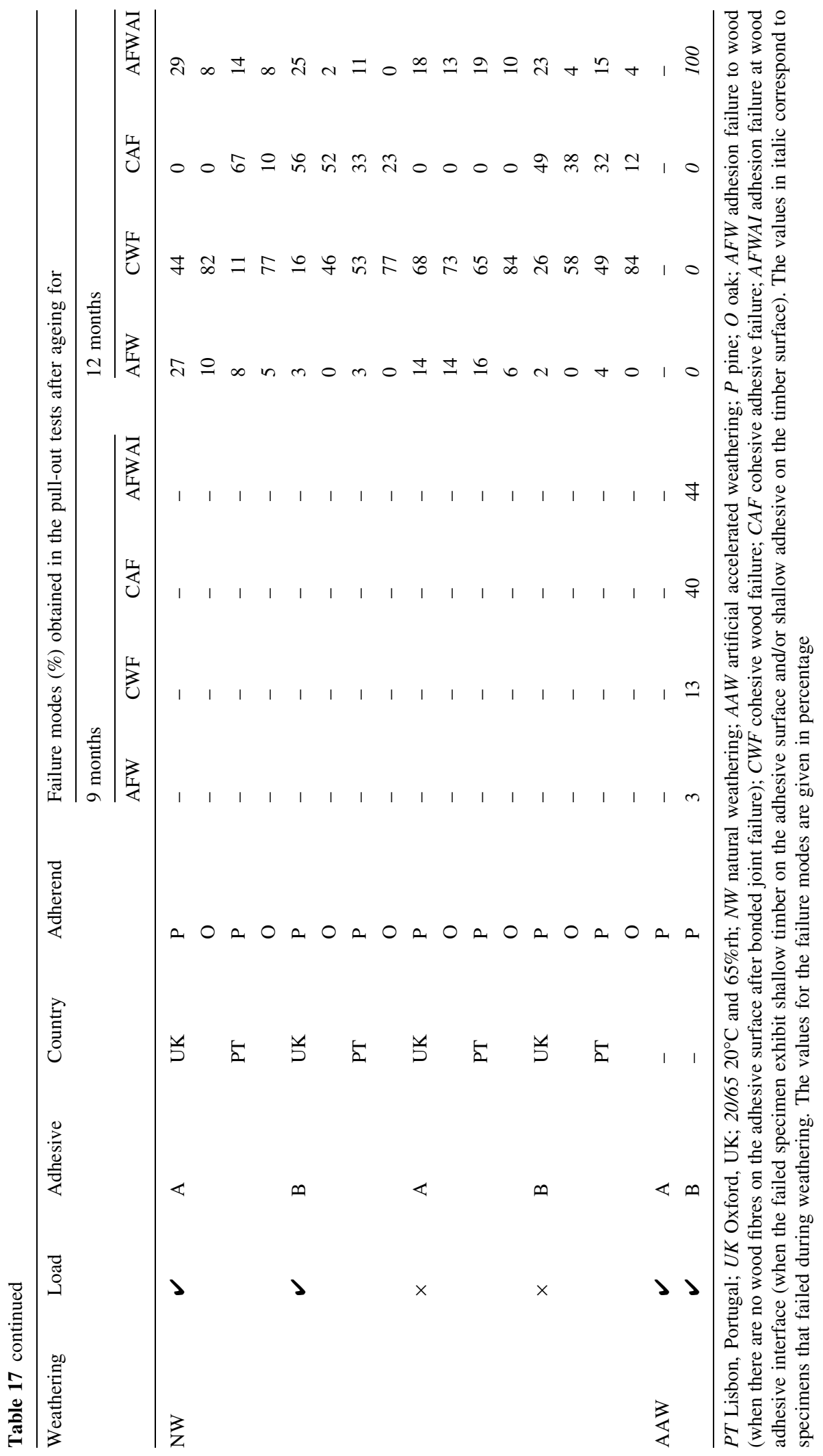


$n \sim \sqrt{\frac{G l^{2}}{2 E t \delta}}$

where $l$ is the lap joint overlap length, $t$ and $\delta$ are adherend and adhesive layer thicknesses, respectively. This equation suggests that for a given adherend, the lower the stiffness of the adhesive used in the bond-line, the lower the stress concentration, giving rise to potentially higher joint strengths. This could explain the larger pull-out strengths obtained with the same timber but more ductile adhesive A. The equation also implies that, for a given adhesive, the stiffer the adherend, the lower the resulting stress concentration, giving rise to higher joint strengths and therefore the higher pull-out strengths obtained with the steel bonded joints.

\subsubsection{Aged specimens}

From the results obtained and without distinguishing between countries, the following general remarks can be made about how the adhesive, timber and adhesive/ timber combination affect the pull-out strength.

After 12 months in a controlled environment (Table 18), the loaded timber specimens bonded with adhesive B registered a decrease in pull-out strength close to but slightly higher than that of the specimens bonded with adhesive A. The reduction in pull-out strength was slightly higher for the oak specimens than for the pine specimens. In terms of timber/ adhesive combination, the greater drop was exhibited by the adhesive $\mathrm{B} / \mathrm{oak}$, followed by adhesive $\mathrm{A} /$ pine, and equally by adhesive B/pine and adhesive A/oak.

After 12 months of natural weathering (Table 18), the loaded timber specimens bonded with adhesive A registered a greater decrease in their pull-out strength compared to the specimens bonded with adhesive B. The pull-out strength reduction was higher for the pine specimens than for the oak specimens. In terms of timber/adhesive combination, the higher pull-out strength reduction was exhibited by adhesive A/pine,
Table 18 Residual pull-out bond strength and pull-out strength variation for the bonded timber specimens
Notes: Adhesive A all bonded joints made with this adhesive, i.e. includes both pine and oak bonded joints; Adhesive $B$ all bonded joints made with this adhesive, i.e. includes both pine and oak bonded joints; Pine all bonded joints made with this timber, i.e. includes joints bonded with adhesives A and B; Oak all bonded joints made with this timber, i.e. includes joints bonded with adhesives A and $\mathrm{B}$

\begin{tabular}{|c|c|c|c|}
\hline Ageing conditions & Bonded joint & $\begin{array}{l}\text { Residual bond } \\
\text { strength }(\%)\end{array}$ & $\begin{array}{l}\text { Pull-out strength } \\
\text { variation }(\%)\end{array}$ \\
\hline \multirow{8}{*}{$\begin{array}{l}\text { Loaded bonded timber } \\
\text { joints after } 12 \text { months in a } \\
\text { controlled environment } \\
\left(20^{\circ} \mathrm{C} \text { and } 65 \% \text { rh }\right)\end{array}$} & Adhesive A & 93.2 & -6.8 \\
\hline & Adhesive B & 91.3 & -8.7 \\
\hline & Pine & 93.2 & -6.8 \\
\hline & Oak & 91.4 & -8.6 \\
\hline & Adhesive $\mathrm{A} /$ pine & 90.6 & -9.4 \\
\hline & Adhesive A/oak & 95.9 & -4.1 \\
\hline & Adhesive B/pine & 95.7 & -4.3 \\
\hline & Adhesive B/oak & 87.0 & -13.0 \\
\hline \multirow{8}{*}{$\begin{array}{l}\text { Loaded timber specimens } \\
\text { after } 12 \text { months of natural } \\
\text { weathering }\end{array}$} & Adhesive A & 88.1 & -11.9 \\
\hline & Adhesive B & 96.0 & -4.0 \\
\hline & Pine & 88.8 & -11.2 \\
\hline & Oak & 95.3 & -4.7 \\
\hline & Adhesive A/pine & 81.8 & -18.2 \\
\hline & Adhesive A/oak & 94.3 & -5.7 \\
\hline & Adhesive B/pine & 95.8 & -4.2 \\
\hline & Adhesive B/oak & 96.2 & -3.8 \\
\hline \multirow{8}{*}{$\begin{array}{l}\text { Unloaded timber specimens } \\
\text { after } 12 \text { months of natural } \\
\text { weathering }\end{array}$} & Adhesive A & 98.7 & -1.3 \\
\hline & Adhesive B & 96.2 & -3.8 \\
\hline & Pine & 99.4 & -0.6 \\
\hline & Oak & 95.5 & -4.5 \\
\hline & Adhesive A/pine & 100.0 & 0 \\
\hline & Adhesive A/oak & 97.4 & -2.6 \\
\hline & Adhesive B/pine & 98.7 & -1.3 \\
\hline & Adhesive B/oak & 93.7 & -6.3 \\
\hline
\end{tabular}


followed by adhesive A/oak, and equally by adhesive $\mathrm{B} /$ pine and adhesive B/oak.

After 12 months of natural weathering (Table 18), the unloaded timber specimens bonded with adhesive $\mathrm{B}$ registered a somewhat greater decrease in their pull-out strength compared to the specimens bonded with adhesive A. The pull-out strength reduction was higher for the oak specimens than for the pine specimens. In terms of timber/adhesive combination, the higher pull-out strength reduction was exhibited by adhesive B/oak, followed by adhesive A/oak, adhesive $\mathrm{B} /$ pine, and adhesive $\mathrm{A} /$ pine.

When a load was present (Table 18), the reduction of the RBS was more significant for the specimens bonded with adhesive $\mathrm{A}$ than with $\mathrm{B}$, and more significant for the pine than for the oak specimens. The worst adhesive/timber combination was adhesive $\mathrm{A} /$ pine followed, at some distance, by adhesive A/oak, adhesive B/pine and adhesive B/oak.

For the weathered specimens (Table 18), the reduction of the RBS was more significant for the specimens bonded with adhesive A than with adhesive $\mathrm{B}$, and likewise for the pine than for the oak specimens. The worst adhesive/timber combination to be affected by the applied load was adhesive $\mathrm{A} /$ pine and adhesive A/oak. Less affected were adhesive B/pine and adhesive B/oak.

Globally, results from both countries (Table 19) show that the weathering and applied long-term load affected the pine specimens bonded with adhesive A much more so, and the oak specimens bonded with adhesive B less so. For the pine specimens bonded with adhesive $\mathrm{A}$ and aged in Oxford, the strong reduction in the pull-out strength, in respect to the other timber/adhesive combinations, was accompanied by an increase of adhesion failure to the wood, to a decrease of cohesive wood failure, and to an increase of adhesion failure at the wood/adhesive interface. For pine specimens bonded with adhesive A aged in Lisbon, the reduction in the pull-out strength, in respect to the other timber/adhesive combinations, was accompanied by a decrease of cohesive wood failure and to an increase in cohesive adhesive failure. For the oak specimens bonded with adhesive B and aged in Oxford, the gain in the pullout strength, in respect to the other timber/adhesive combinations, was due to the improvement of the adhesive's viscoelastic properties, since the small decrease of cohesive wood failure and small increase
Table 19 Pull-out strength variation for the weathered and loaded bonded timber specimens

\begin{tabular}{|c|c|c|c|c|}
\hline \multirow[t]{2}{*}{$\begin{array}{l}\text { Difference } \\
\text { between }\end{array}$} & \multirow[t]{2}{*}{ Bonded joint } & \multicolumn{3}{|c|}{$\begin{array}{l}\text { Pull-out strength } \\
\text { variation }(\%)\end{array}$} \\
\hline & & $\begin{array}{l}\text { PT \& } \\
\text { UK }\end{array}$ & UK & PT \\
\hline \multirow{8}{*}{$\begin{array}{l}\text { Weathered and } \\
\text { non-weathered } \\
\text { specimens }\end{array}$} & Adhesive A & -5.2 & -11.3 & 1.0 \\
\hline & Adhesive B & 4.6 & -1.8 & 11.1 \\
\hline & Pine & -4.3 & -12.3 & 3.7 \\
\hline & Oak & 3.8 & -0.8 & 8.5 \\
\hline & Adhesive A/pine & -8.8 & -16.7 & -0.9 \\
\hline & Adhesive A/oak & -1.5 & -5.9 & 2.9 \\
\hline & Adhesive B/pine & 0.1 & -8.0 & 8.3 \\
\hline & Adhesive B/oak & 9.2 & 4.3 & 14.0 \\
\hline \multirow{8}{*}{$\begin{array}{l}\text { Loaded and } \\
\text { unloaded } \\
\text { specimens }\end{array}$} & Adhesive A & -10.6 & -6.9 & -14.3 \\
\hline & Adhesive B & -0.2 & -0.9 & 0.5 \\
\hline & Pine & -10.5 & -9.5 & -11.6 \\
\hline & Oak & -0.3 & 1.7 & -2.2 \\
\hline & Adhesive A/pine & -18.2 & -13.9 & -22.4 \\
\hline & Adhesive A/oak & -3.1 & 0.1 & -6.2 \\
\hline & Adhesive B/pine & -2.9 & -5.1 & -0.7 \\
\hline & Adhesive B/oak & 2.5 & 3.3 & 1.7 \\
\hline
\end{tabular}

Notes: Adhesive A refers to all bonded joints made with this adhesive, i.e. includes both pine and oak bonded joints; Adhesive $B$ refers to all bonded joints made with this adhesive, i.e. includes both pine and oak bonded joints; Pine refers to all bonded joints made with this timber, i.e. includes joints bonded with adhesives A and B; Oak refers to all bonded joints made with this timber, i.e. includes joints bonded with adhesives A and B. PT Lisbon, Portugal; UK Oxford, UK

of cohesive adhesive failure registered would be consistent with a weaker joint. For oak specimens bonded with adhesive B aged in Lisbon, the gain in the pull-out strength, with respect to the other timber/ adhesive combinations, was consistent with an increase in cohesive wood failure and a decrease of cohesive adhesive failure and of adhesion failure at wood/adhesive interface.

\subsubsection{Artificially aged specimens}

The artificially accelerated weathered specimens did not withstand 12 months of ageing. The ones bonded with adhesive A failed after being exposed to only half of the first cycle, while the specimens bonded with adhesive B lasted longer, failing after 9 months. 
Adhesives A bonded joints failed cohesively in the adhesive, and adhesive B bonded joints adhesively at the wood/adhesive interface (Fig. 8).

The decrease in pull-out strength during the AAW was linear up to 9 months, beyond which the remaining specimens failed within the next 3 month period (Fig. 9). In addition, the joint deformation observed for adhesive B increased linearly in those 9 months, but as the failure occurred on the interface, creep should not be solely used to predict joint life. Thus, for durability predictions it seems better to compare time to failure than residual strength or creep progress independently.

After 9 months of AAW the specimens' RBS decreased $26.0 \%$ in respect to the initial value. No pine specimens bonded with adhesive $\mathrm{B}$ in the other ageing regimes showed a similar decrease in the first 12 months of ageing. The closest result was obtained with the specimens aged naturally in Oxford for 12 months, which recorded a decrease of $12.3 \%$. After 12 months, the specimens aged in Lisbon still
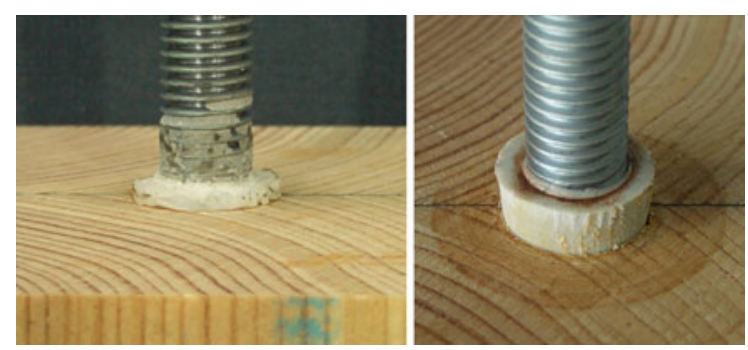

Fig. 8 Pine specimens failure during the artificial accelerated weathering: cohesive adhesive failure obtained on adhesive A specimens after 1 week of AAW (left); adhesion failure at the timber/adhesive interface obtained on adhesive B specimens after 9 months of AAW (right)

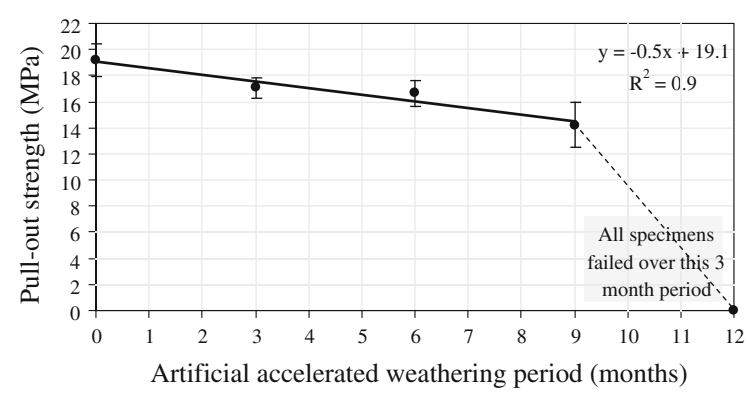

Fig. 9 Pull-out tests results for the pine specimens bonded with adhesive $\mathrm{B}$ and aged artificially had a RBS higher than the initial RBS, whilst those kept in a controlled environment still exhibited $96 \%$ of the initial strength.

The specimens aged artificially showed cracks and fissures in the timber and in the adhesive (Fig. 10). The specimens aged naturally and tested thus far, did not present any visible fissures either in the timber (pine and oak), or in the adhesive (A and B). This is indicative of accelerated ageing, whereby the cycle imposes more severe conditions than those registered naturally.

As the ageing progressed, the bond strength reduction was accompanied by a decrease in the percentage of cohesive wood failure and of cohesive adhesive failure, and by an increase in failure at the wood/adhesive interface. It should be pointed out that, in practice, the bond degradation will not proceed as quickly as in any of the situations presented here, since strictly all of the tests were in fact accelerated weathering tests. This is due to the very small ratio of adhesive anchorage length to rod diameter (not usual for established design practice, which was deliberately adopted as a "border' condition in order to study the joint behaviour) and the fact that the bond-line is not concealed inside the timber element. These factors imply that the bondline is more exposed to the elements and there is a greater stress state in the short bond length than would be the case in practice.

\subsubsection{Creep}

The results presented here refer to the bonded timber specimens subjected to natural and AAW for 12 months. Table 20 and Fig. 11 show the creep obtained during ageing.

Comparing the creep behaviour, after 12 months, of the specimens kept in a controlled environment $\left(+4.2 \%^{1}\right)$ with that of the naturally $(+7.8 \%)$ and artificially aged $(+22.3 \%)$, it was found that, as might be expected, adhesive A showed more creep $(+13.1 \%)$ than adhesive B $(+4.6 \%)$. Globally, the specimens aged in Lisbon had a more pronounced increase in creep value $(+12.2 \%$ for Lisbon and

\footnotetext{
$\overline{1}$ The values in parentheses represent the creep variation in percentage.
} 

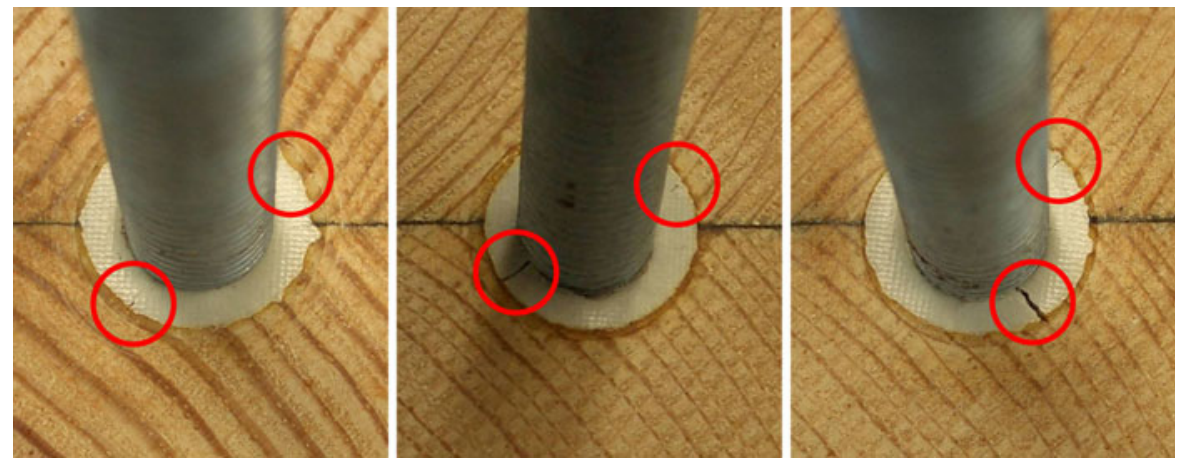

Fig. 10 Examples of fissures developed in the pine timber specimens bonded with adhesive B during the artificial accelerated weathering

Table 20 Creep results for timber specimens unexposed and exposed to natural and artificial accelerated weathering

\begin{tabular}{|c|c|c|c|c|c|c|c|c|c|c|c|c|c|}
\hline \multirow{3}{*}{$\begin{array}{l}\text { Weathering } \\
\\
\times\end{array}$} & \multirow{3}{*}{$\frac{\text { Load }}{v}$} & \multirow{3}{*}{$\begin{array}{l}\text { Adhesive } \\
\text { A }\end{array}$} & \multirow{3}{*}{$\begin{array}{l}\text { Country } \\
-\end{array}$} & \multirow{3}{*}{$\begin{array}{l}\text { Timber } \\
\mathrm{P}\end{array}$} & \multirow{3}{*}{$\begin{array}{c}\text { Code } \\
\text { XAP }\end{array}$} & \multicolumn{8}{|c|}{ Creep $(\mathrm{mm})$ obtained after ageing for } \\
\hline & & & & & & \multicolumn{2}{|c|}{3 months } & \multicolumn{2}{|c|}{6 months } & \multicolumn{2}{|c|}{9 months } & \multicolumn{2}{|c|}{12 months } \\
\hline & & & & & & 0.25 & 0.01 & 0.32 & 0.01 & - & - & 0.60 & 0.01 \\
\hline & & & & $\mathrm{O}$ & XAO & 0.30 & 0.02 & 0.40 & 0.02 & - & - & 0.69 & 0.02 \\
\hline & $\boldsymbol{V}$ & $\mathrm{B}$ & - & $\mathrm{P}$ & XBP & 0.00 & 0.01 & 0.00 & 0.01 & - & - & 0.00 & 0.02 \\
\hline & & & & $\mathrm{O}$ & $\mathrm{XBO}$ & 0.01 & 0.01 & 0.01 & 0.01 & - & - & 0.05 & 0.01 \\
\hline \multirow[t]{8}{*}{ NW } & $v$ & A & UK & $\mathrm{P}$ & NWKAP & 0.33 & 0.01 & 0.40 & 0.01 & - & - & 0.52 & 0.01 \\
\hline & & & & $\mathrm{O}$ & NWKAO & 0.32 & 0.02 & 0.48 & 0.02 & - & - & 0.58 & 0.02 \\
\hline & & & PT & $\mathrm{P}$ & NWTAP & 1.59 & 0.01 & 2.12 & 0.00 & - & - & 1.68 & 0.01 \\
\hline & & & & $\mathrm{O}$ & NWTAO & 1.23 & 0.01 & 1.69 & 0.01 & - & - & 1.77 & 0.01 \\
\hline & $\checkmark$ & B & UK & $\mathrm{P}$ & NWKBP & 0.18 & 0.01 & 0.03 & 0.01 & - & - & 0.05 & 0.01 \\
\hline & & & & $\mathrm{O}$ & NWKBO & 0.12 & 0.02 & 0.02 & 0.02 & - & - & 0.01 & 0.02 \\
\hline & & & PT & $\mathrm{P}$ & NWTBP & 0.27 & 0.01 & 0.28 & 0.01 & - & - & 0.33 & 0.01 \\
\hline & & & & $\mathrm{O}$ & NWTBO & 0.25 & 0.01 & 0.26 & 0.01 & - & - & 0.22 & 0.02 \\
\hline \multirow[t]{2}{*}{ AAW } & $\checkmark$ & $\mathrm{A}$ & - & $\mathrm{P}$ & AAWAP & $\mathrm{a}$ & - & - & - & - & - & - & - \\
\hline & $\nu$ & B & - & $\mathrm{P}$ & AAWBP & 0.43 & 0.01 & 0.58 & 0.01 & 0.93 & 0.01 & - & - \\
\hline
\end{tabular}

Notes: Creep 3 months: ${ }^{a}$ specimens failed after 1 week of AAW. Codes $-X$ specimens kept in controlled environment $\left(20^{\circ} \mathrm{C}-\right.$ $65 \% \mathrm{rh})$

$A$ adhesive A; $B$ adhesive B; $P$ pine; $O$ oak; $N W$ natural weathering; $A A W$ artificial accelerated weathering; $U K=O x f o r d, U K ; P T$ Lisbon, Portugal

$+3.4 \%$ for Oxford), which is consistent with the more severe weathering conditions in Lisbon (Table 13).

The weathering resulted in an increase in creep for all adhesives and timbers as compared to the nonweathered. Adhesive A specimens registered a similar increase in creep when bonded to pine or oak ( $\sim 5.2$ to $5.7 \%)$. Adhesive B specimens also registered similar increases in creep when bonded to pine or oak $(\sim 1.0$ to $2.2 \%)$.
Comparing the difference in creep between the unaged and aged specimens it was found that all the adhesive/timber combinations in Lisbon registered an increase of $7.9 \%$ after 12 months, whilst those aged in Oxford registered negligible change. More specifically, the timber/adhesive combinations in Lisbon presented the following increases in creep: adhesive A/oak $+12.9 \%$, adhesive $\mathrm{A} /$ pine $+11.7 \%$, adhesive $\mathrm{B} /$ pine $+4.2 \%$ and adhesive $\mathrm{B} / \mathrm{oak}+2.8 \%$. 


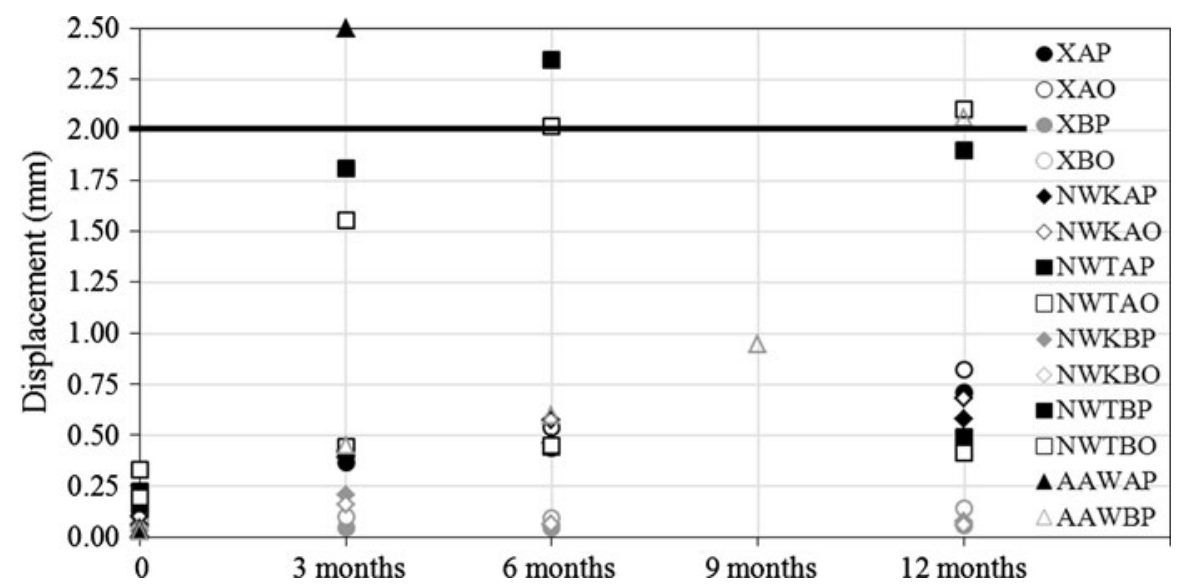

Fig. 11 Creep results for timber specimens unexposed and exposed to natural and artificial accelerated weathering. Bar indicates when adhesive reaches the bottom of the washers' free area (see Fig. 1). Codes $-X$ specimens kept in controlled

Considering creep values for adhesive $\mathrm{B} /$ pine specimens aged naturally and artificially over 12 months it was observed that:

- 12 months in a controlled environment corresponded to $\sim 9$ days of AAW;

- 12 months of natural weathering in Oxford corresponded to $\sim 14$ days of AAW;

- 12 months of natural weathering in Lisbon corresponded to $\sim 136$ days of AAW.

However, as the creep in the second semester did not increase as much as in the first 6 months, more reliable comparisons can only be made with longer weathering time. No considerations can be made about the creep of adhesive A/pine specimens subjected to AAW, since they failed immediately after the first half of the weathering cycle. However, considering the specimens that failed during exposure, it was seen that some of the pine specimens bonded with adhesive A, and aged in Lisbon, failed after the first 3 months, thus indicating that 3 months of natural weathering in Lisbon correspond to $\sim 7$ days of AAW for this adhesive.

\section{Conclusions}

Connections and reinforcement employing rods bonded into timber have been used for many years. Although these connections have been found to exhibit high initial bond strengths to timber, and environment $\left(20^{\circ} \mathrm{C}-65 \% \mathrm{rh}\right) ; A$ adhesive A; $B$ adhesive $\mathrm{B}$; $P$ pine; $O$ oak; $N W$ natural weathering; $A A W$ artificial accelerated weathering; $U K$ Oxford, UK; $P T$ Lisbon, Portugal

excellent durability in applications with other substrates, no test standards or commonly accepted specifications exist today for assessing and approving adhesives to be used for on-site bonded-in rod applications.

Industry is dependent upon accelerated tests for determining the durability and suitability of an adhesive for a specific application. The current standardised tests used for assessing in-use performance of bonded assemblies (Table 1) were developed for phenolic and aminoplastic adhesives bonded to softwoods through thin bond-lines $(<1.0 \mathrm{~mm})$, in other words they focus mainly on the performance and durability of glulam type materials. Consequently, the established acceptance criteria are very conservative and are not adequate for applications using dense hardwoods or highly cross-linked in situ polymerized adhesives in thick bond-lines, e.g., twocomponent epoxy adhesives. In these cases, the too stringent acceptance criteria of the existing standards will most likely impede most of the existing epoxy adhesives to be used for structural rehabilitation, thus hindering their widespread usage. An attempt to rectify this situation was addressed with the test methodology undertaken in this project.

The most important features of the developed method are: (a) the direct evaluation of all the components involved in the repair/strengthening system, thus accounting for all the possible crossinfluences of the different materials bonded together; (b) the exposure to a realistic load and realistic ageing 
conditions; (c) the use of small scale bonded assemblies requiring minimal space so that a number of different systems can be tested simultaneously in an environmental cabinet; (d) the absence of complicated jigs (labour intensive and with complex parts) and weathering equipment (e.g., vacuum and pressure chambers); and (e) the relative short-time period needed to obtain a result for unsuitable materials.

The data provided by the ongoing natural weathering tests will ensure that the developed methodology is predicting correctly the end-use performance for different adhesives as well as for different timbers and connecting elements. Since for an accelerated test to be an accurate predictor, the mode of failure in both the accelerated test and end use must be the same, thus the results obtained so far are a good indicator of the validity of the method.

\subsection{Summary of research findings}

The results obtained in this project [1] revealed that:

- The service conditions to which bonded-in rod connections may be subjected to may involve long periods with temperatures up to $50^{\circ} \mathrm{C}$ and humidities up to $80 \%$. More extreme conditions may be possible in other countries or regions.

- A more realistic experimental methodology can be used to assess the durability of bonded joints between timber and various adhesives and connecting materials suitable for the rehabilitation of timber structures.

- The test specimen's geometry and ageing conditions used in a durability test are of the upmost importance, because wood geometry aspects (e.g. thickness, width, length, grain direction) will control the response to temperature and relative humidity and thus the amount of stress that the bond-line will be subjected to during service.

- Any service life predictive models should take into account, not only the variation in the properties of the bulk components with exposure, but also the increase/decrease in pull-out strength, creep and failure modes (cohesive adhesive failure and adhesion failure at the timber/adhesive interface).

- In general, the results indicate that approval and certification of structural adhesives for bonded-in rods should include additional requirements to those defined in EN 301, such as the acceptance criteria $^{2}$ suggested in [1].

The experimental tests performed using the developed test procedure enabled investigations into the influence of environmental conditions, load, adhesive type and timber species on the long-term joint integrity.

From the results it seems that the experimental method developed can be used to assess the durability of bonded joints between timber and various adhesives and connecting materials suitable for structural timber rehabilitation. It was seen that the various ageing conditions have a quite different effect on the bulk adhesive properties and on the bonded joint performance, thus the un-realistic conditions (very harsh weathering cycles or very high loads on shortterm tests) used on the existing standards [9-20] should be avoided and replaced by a more realistic artificial accelerated weathering cycle, like the one proposed in this project.

Acknowledgments This work was carried out at Oxford Brookes University within the scope of a $\mathrm{PhD}$ research project (SFRH/BD/17210/2004/DGW8) financed by "Fundação para a Ciência e a Tecnologia (Portugal, POCI 2010 - Formação Avançada para a Ciência - Medida IV.3)". The authors wish to acknowledge this financial support.

\section{References}

1. Custódio J (2009) Performance and durability of composite repair and reinforcement systems for timber structures. PhD Dissertation, Oxford Brookes University, Oxford

2. Cruz H, Custódio J (2010) Adhesives for on-site rehabilitation of timber structures. J Adhes Sci Technol 24(8):1473-1499. doi:10.1163/016942410X501089

3. Dunky M, Källender B, Properzi M, Richter K, Leemput MV (eds) (2008) Core document of the COST Action E34-bonding of timber. Lignovisionen, Special edition. University of Natural Resources and Applied Life Sciences, Vienna

4. Machado JS, Cruz H, Custódio J, Palma P, Dias A (2009) Avaliação, Conservação e Reforço de Estruturas de Madeira [Evaluation, conservation and reinforcement of timber structures]. Verlag Dashöfer, Lisboa

\footnotetext{
${ }^{2}$ As the acceptance criteria were developed not only from this durability test, but also from other tests performed on the bulk adhesives, not presented here, it was decided not to include them in this article, and instead reference the author to the publication where the reader can have a global view of the development process of the acceptance criteria.
} 
5. Broughton JG, Custódio J (2009) Understanding timber structural connection systems. In: Forde MC (ed) ICE manual of construction materials, vol 2. Thomas Telford Ltd, London, pp 739-760

6. Custódio J, Broughton J, Cruz H (2009) A review of factors influencing the durability of structural bonded timber joints. Int J Adhes Adhes 29(2):173-185. doi:10.1016/ j.ijadhadh.2008.03.002

7. Cruz H, Custódio J (2006) Thermal performance of epoxy adhesives in timber structural repair. Paper presented at the 9th world conference on Timber engineering (WCTE) 2006, Portland, OR, USA, 6-10 August 2006

8. Custódio J, Cruz H, Broughton J (2008) Preparation method and service conditions effects on the performance and durability of epoxy adhesives used in structural timber repairs. Paper presented at the 11th international conference on Durability of building materials and components (DBMC) 2008, Istanbul, Turkey, 11-14 May 2008

9. ASTM D2919-01. Standard test method for determining durability of adhesive joints stressed in shear by tension loading. ASTM International, West Conshohocken (PA)

10. ASTM D3535-07a. Standard test method for resistance to creep under static loading for structural wood laminating adhesives used under exterior exposure conditions. ASTM International, West Conshohocken (PA)

11. ASTM D4680-98 (2004) Standard test method for creep and time to failure of adhesives in static shear by compression loading (wood-to-wood). ASTM International, West Conshohocken (PA)

12. EN 14292:2005. Adhesives. Wood adhesives. Determination of static load resistance with increasing temperature. European Committee for Standardization (CEN), Brussels

13. ASTM D2559-04. Standard specification for adhesives for structural laminated wood products for use under exterior (wet use) exposure conditions. ASTM International, West Conshohocken (PA)

14. EN 301:2006. Adhesives, phenolic and aminoplastic, for load-bearing timber structures. Classification and performance requirements. European Committee for Standardization (CEN), Brussels

15. EN 302-1:2004. Adhesives for load bearing timber structures. Test methods. Determination of bond strength in longitudinal tensile shear strength. European Committee for Standardization (CEN), Brussels

16. EN 302-2:2004. Adhesives for load-bearing timber structures. Test methods. Determination of resistance to delamination. European Committee for Standardization (CEN), Brussels

17. Standard Proposal CEN TC193/SC1/WG11 N21 (2003) Adhesives for on-site assembling or restoration of timber structures. On-site acceptance testing. Verification of the adhesive joint's shear strength. European Committee for Standardization (CEN), Brussels

18. Standard Proposal CEN TC193/SC1/WG11 N260 (2003) Adhesives for on-site assembling or restoration of timber structures. Comparative evaluation of the shear strength of adhesive joints and solid wood. European Committee for Standardization (CEN), Brussels

19. Standard Proposal CEN TC193/SC1/WG11 N22 (2003) Adhesives for on-site assembling or restoration of timber structures. On-site acceptance testing. Verification of the adhesive bond strength using tensile proof-loading. European Committee for Standardization (CEN), Brussels

20. Standard Proposal CEN TC193/SC1/WG11 N48 (2005) Adhesives for on-site assembling or restoration of timber structures. Evaluation of the shear strength of tubular adhesive joints. European Committee for Standardization (CEN), Brussels

21. Bainbridge R, Mettem C, Harvey K, Ansell M (2002) Bonded-in rod connections for timber structures-development of design methods and test observations. Int $\mathrm{J}$ Adhes Adhes 22(1):47-59

22. Madhoushi M, Ansell MP (2004) Experimental study of static and fatigue strengths of pultruded GFRP rods bonded into LVL and glulam. Int J Adhes Adhes 24(4):319-325

23. Weather Underground, Inc. Weather station located at Lisbon Airport-http://english.wunderground.com/history/ airport/LPPT/, weather station located at Heathrow Airport-http://english.wunderground.com/history/airport/ EGLL/. Accessed 31 Dec 2008

24. EN 1383:1999 Timber structures. Test methods. Pull through resistance of timber fasteners. European Committee for Standardization (CEN), Brussels

25. Feligioni L, Lavisci P, Duchanois G, de Ciechi M, Spinelli $P$ (2003) Influence of glue rheology and joint thickness on the strength of bonded-in rods. Holz Roh Werkst 61(4): 281-287

26. Thelandersson S, Larsen HJ (eds) (2003) Timber engineering. Wiley, Chichester 